Max-Planck-Institut für demografische Forschung

Max Planck Institute for Demographic Research

Konrad-Zuse-Strasse 1 - D-18057 Rostock - GERMANY

Tel +49 (0) 3812081 - 0; Fax +49 (0) 3812081 - 202;

http://www.demogr.mpg.de

MPIDR WORKING PAPER WP 2015-010

NOVEMBER 2015

\title{
Secular changes in the association \\ between advanced maternal age and \\ the risk of low birth weight: \\ a cross-cohort comparison in the UK
}

\author{
Alice Goisis \\ Daniel Schneider (schneider@demogr.mpg.de) \\ Mikko Myrskylä
}

(C) Copyright is held by the authors.

Working papers of the Max Planck Institute for Demographic Research receive only limited review. Views or opinions expressed in working papers are attributable to the authors and do not necessarily reflect those of the Institute. 


\title{
Secular changes in the association between advanced maternal age and the risk of low birth weight: a cross-cohort comparison in the UK
}

\author{
Alice Goisis [1,2] \\ Daniel Schneider [2] \\ Mikko Myrskylä [1,2,3] \\ [1] Department of Social Policy, London School of Economics and Political Science \\ [2] Max Planck Institute for Demographic Research \\ [3] Population Research Unit, University of Helsinki
}

\begin{abstract}
Existing studies provide contradictory evidence concerning the association between child well-being and advanced maternal ages. A potential explanation for the lack of consensus are changes over time in the costs and benefits of giving birth at advanced ages. This is the first study that tests secular changes in the association between advanced maternal age and child health. We use data from four UK cohort studies covering births from 1958-2001, and use low birth weight as a marker for child health. We find that across successive birth cohorts, the association between advanced maternal age and low birth weight becomes progressively weaker, and is negligible statistically and substantively for the 2001 cohort. Among current cohorts advanced maternal age does not predict low birth weight, but if selection into older maternal ages had not changed, it would still predict strongly increased risk of giving birth to a low birth weight child.
\end{abstract}




\section{KEYWORDS}

NCDS National Child Development Study

BCS British Cohort Study

ALSPAC Avon Longitudinal Study of Parents and Children

MCS Millennium Cohort Study

LBW Low Birth Weight 


\section{Introduction}

Since the 1970s, there has been a marked increase in childbearing postponement in developed countries (Sobotka, 2004). This trend has in turn led to a sharp increase in the mean age at first birth and in births at advanced maternal ages (Billari et al., 2007). Yet even as childbearing postponement has become common across the entire developed world, whether and to what extent women should be advised against giving birth at advanced ages because of the associated health risks are issues that are still being debated (Tough et al., 2002). One reason why there is no general consensus on the question of "how old is too old" (Heffner, 2004) is the growing awareness that evidence from earlier periods might not accurately reflect the contemporary association between maternal age and child well-being. Whereas in earlier periods an advanced maternal age at birth was associated with high parity and low socioeconomic status, today advantaged women are more likely than disadvantaged women to give birth at an older age (Prioux, 2005). It would therefore be reasonable to expect that older mothers and their children face lower risks of poor health outcomes today than they did two or more decades ago (Carolan, 2003). Up to now, however, no study has analysed whether this is the case.

This is the first study that has analysed whether the characteristics of older mothers and the association between advanced maternal age and child well-being have changed over time. As a measure of child well-being, we focus on low birth weight (LBW), which is marker of child health at the time of birth and an important determinant of health and socio-demographic outcomes later in life (Jefferis et al., 2002, Black et al., 2007, Reichman, 2005). We use data from four birth cohort studies covering births that took place in different parts of the UK between 1958 and 2001. We find that across successive birth cohorts, older mothers have become more advantaged, and that an advanced maternal age has become progressively less likely to be associated with LBW. Indeed, in the most recent birth cohort studied, the association is shown to be both statistically and substantively negligible. The decline in the association can be partially explained by secular changes in the characteristics of older mothers. Moreover, the overall improvement in the epidemiological context of childbearing may have contributed to the decline. 


\section{Background}

The association between advanced maternal age and child health remains a highly controversial topic. The medical literature has expressed concerns about late childbearing, with many studies suggesting that in terms of pregnancy outcomes, the optimal age range for childbearing is 20-35 (Bewley et al., 2005). This argument is based on evidence that women who give birth after age 35, and especially after age 40, face increased risks of ante-partum, intra-partum, and post-partum complications. The risks range from a higher incidence of miscarriage, high blood pressure, preeclampsia, gestational diabetes, and chromosomal abnormalities; to problematic neonatal outcomes, such as preterm delivery and low birth weight (Aldous and Edmonson, 1993, Fretts et al., 1995, Hansen, 1986, Jolly et al., 2000).

However, other studies have found no or limited evidence of increased risks of adverse pregnancy outcomes associated with advanced maternal age (Kirz et al., 1985, Barkan and Bracken, 1987, Berkowitz et al., 1990, Cunningham and Leveno, 1995, Carolan and Frankowska, 2011). For example, while older mothers face higher risks of operative delivery (e.g., C-section) and morbidity (e.g., gestational hypertension), neonatal outcomes do not appear to be affected (Ziadeh and Yahaya, 2001, Bianco et al., 1996).

One potential reason why there is no general consensus about the risks associated with giving birth at advanced maternal ages is that the association may be changing over time. It has been argued, but not tested empirically, that mothers who give birth at an advanced age today face lower risks of poor neonatal outcomes than their counterparts two or three decades ago (Carolan, 2003).

There are several mechanisms through which the risks associated with giving birth at an advanced maternal age could have declined. First, the risks may be lower today than they were several decades ago because the socio-demographic characteristics of older mothers have changed. In a contemporary developed country like the UK, the geographical focus of this study, older mothers are, on average, a particularly advantaged subsection of the population, as they tend to be highly educated and employed in professional occupations (Bray et al., 2006, Hawkes et al., 2004, Goisis, 2015). Conversely, in the past a child who was born to an older mother was more likely than average to have been a higher order birth, and to have been born into a 
family that was large and relatively poor (Prioux, 2005). Because there were fewer socio-economic incentives associated with giving birth at older ages, older mothers were a more heterogeneous group in the past than they are today. Moreover, knowledge about the connection between health behaviours during pregnancy and birth outcomes has improved considerably over time. For example, in the UK, as in many developed contexts, knowledge about the detrimental effects of smoking during pregnancy and birth outcomes was not widespread until the 1970s. Thus, we expect that smoking during pregnancy has become more selective of disadvantaged and younger mothers. For example, Fertig (2010), using data from three of the UK birth cohorts, showed that the association between maternal age and smoking during pregnancy has changed considerably over time: the results indicated that mothers aged 34 and over who gave birth around the year 2001 were considerably less likely than their younger counterparts to have smoked during pregnancy, and that there was no age gradient for mothers who gave birth in 1958 or 1970.

Second, the risks associated with giving birth at an advanced maternal age could have declined as a result of the changes in the medical and epidemiological contexts surrounding childbearing. The introduction of prenatal screenings has helped to reduce the number of negative birth outcomes associated with advanced maternal age (Myrskylä and Fenelon, 2012), as these screenings have made it easier to detect genetic abnormalities and identify problematic pregnancies in the early stages. There have been significant advancements in postnatal care as well. In the UK, for example, special baby care units were introduced in the 1960s, neonatal intensive care was introduced in the 1970s, and further technological and pharmacological advancements were made during the 1970s and 1980s (Dunn, 2006). Modern neonatal technology has contributed to the reduction in complications arising from poor health outcomes at birth (Hack et al., 1995). It therefore appears likely that these improvements in obstetric care have made the risks associated with giving birth at an advanced maternal age more manageable than they were in the past (Carolan, 2003). Moreover, overall improvements in medical practice and services may have helped to slow down the natural health deterioration and “reproductive ageing” processes. Thus, today's older mothers may be healthier than they were in the past.

Over time, changes in the characteristics of older mothers and in the context surrounding childbearing might have resulted in systematic changes in the costs and 
benefits of giving birth at advanced ages. In this study, we aim to empirically test for the first time whether there have been secular changes in the characteristics of older mothers, and thus in the association between advanced maternal age and giving birth to a LBW child.

\section{Data}

To examine the secular trends in the association between advanced maternal age and child health around the time of birth, we made use of four of the UK birth cohort studies $^{\mathrm{i}}$ that cover individuals born in the UK over a 40-year time period. These surveys are longitudinal, but because our focus in this study is on the association between maternal age and child health at the time of birth, we include only the data collected in the first sweep, which looked at birth outcomes. The focus of the analyses is on the cohort members' birth weight and their mother's age at birth.

1958 National Child Development Study (NCDS)

The 1958 NCDS is a longitudinal cohort study of all children born (including stillborn) in England, Scotland, and Wales during one particular week of March 1958. The study has its origins in the Perinatal Mortality Survey, and later became known as the NCDS or the 1958 birth cohort study. The Perinatal Mortality Survey collected information on around 17,500 babies. The birth survey was completed by a midwife who attended the delivery, and who interviewed the mother after the birth of the cohort child. In the case of a stillbirth or a neonatal death, a clinical summary was also completed by the midwife and medical attendants. The response rate from the birth survey was $98.8 \%$.

\section{British Cohort Study (BCS)}

The 1970 BCS is a longitudinal cohort study of all children born (including stillbirths) in England, Scotland, and Wales during one particular week of April 1970. The birth survey collected information on around 17,200 babies. As in the NCDS, the birth survey was completed by the midwife who attended the birth, and was complemented with clinical information. The response rate for the birth survey was 95.9\%. 
1992 Avon Longitudinal Study of Parents and Children (ALSPAC) ${ }^{i i}$

The ALSPAC is a longitudinal cohort study of children born in the county of Avon between April 1991 and 31 December 1992. ${ }^{\text {iii }}$ The study targeted pregnant women who were living in the catchment area of the county of Avon (Boyd et al., 2013). The “eligible sample” consisted of 20,248 pregnant women, of whom 14,541 (71.8\% of the eligible sample) were recruited. A total of 14,062 of these women had a live birth. Unlike the other cohort studies used in this study, the ALSPAC is not nationally representative. However, its inclusion in our analysis allows us to fill in a 30-year gap between the BCS and the MCS during which no nationally representative data were collected. Of the four cohort studies analysed here, the ALSPAC is the only one in which interviews were conducted during pregnancy, and is therefore the only one that used variables collected before, as well as after, the time of birth. The birth weight of each child is taken from obstetric records collected at the time of birth. For ease of exposition, we refer to the ALSPAC as the 1992 cohort study, since the majority of the births in this sample occurred in 1992.

\section{Millennium Cohort Study (MCS)}

The MCS is a longitudinal cohort study of around 19,000 children born in England, Scotland, Wales, and Northern Ireland in 2000-2001 (Hansen, 2008). It is the most recent representative cohort study collected in the UK. The first sweep was collected when the cohort children were around nine months old. In most cases, the main respondent was the cohort child's biological mother. Mothers' reports of information related to the pregnancy and the time of birth could be subject to bias, especially as the information was collected when the children were around nine months old. However, prior studies suggest that mothers' reports of birth weight tend to be reliable and in line with registration data (Tate et al., 2005). Throughout the analyses, we excluded cases in which the main respondent was not the biological mother. Selected wards were disproportionately sampled to over-represent areas of high child poverty, concentrations of ethnic minorities, and the three smaller countries of the UK (Scotland, Wales, and Northern Ireland). For this reason, weights were used in the analyses to rebalance the survey and to account for its complex structure. The response rate was 68\%. For ease of exposition, we refer to the MCS as the 2001 cohort study, as the majority of the births in the sample occurred in 2001. 


\section{Measures}

Our outcome is a binary variable indicating whether the cohort child was born low birth weight (LBW), which is defined as a birth weight below $2.5 \mathrm{~kg}$. We chose this marker for three reasons. First, existing studies have shown that LBW is the most important determinant of neonatal and infant morbidity (Boardman et al., 2002), and that it appears to be an indicator of the individual's chances later in life (Black et al., 2007, Figlio et al., 2014). Second, as many studies have shown that older women are more likely than younger women to give birth to a LBW baby (Aldous and Edmonson, 1993), birth weight is a relevant outcome given the scope of this study. Third, because birth weight data were collected in the four cohort studies, we are able to investigate the secular changes in the association between advanced maternal age and child health. Because we rely on LBW as a marker of chances later in life, stillbirths were excluded from the 1958 NCDS and the 1970 BCS samples. ${ }^{\text {iv }}$

In order to investigate the association between maternal age and LBW across cohorts, we have divided the mothers' ages at birth into six categories: under 20, 20-24, 25-29, 30-34, 35-39, and 40 and over. Throughout the analyses, 25-29 is used as the reference category since in all of the cohort studies this was the age group with the lowest prevalence of LBW. Using 20-24 as the reference category produces qualitatively similar results (see Appendix Figure A2 and Appendix Table A7). We define the mothers who gave birth at an advanced age as those aged 40 and above, as a large body of literature has indicated that the association between advanced maternal age and adverse birth outcomes becomes clinically relevant after this age threshold (Mills and Lavender, 2011).

Throughout the analyses, we consider an extensive set of covariates that are used (as discussed in the next section) first to describe the characteristics of the mothers by the age when they gave birth, and then to explore how their inclusion in regression models modifies the estimated association between maternal age and the risk of giving birth to a LBW child. The evidence suggests that with the older mothers who gave birth recently had, on average, a higher socio-economic status and better health behaviours than the younger mothers (McLanahan, 2004, Martin, 2004b, Carolan, 2003). However, we do not know whether this was true to the same extent or at all for the mothers who gave birth at advanced ages in previous decades. Conversely, we 
expect to find that the older mothers in all of the cohorts had more complicated pregnancies than the younger mothers. Again, however, it is unclear whether complications occurred to the same extent across cohorts. Maternal age is a marker of both socio-demographic and health characteristics, and the interaction between these two sets of characteristics might determine whether mothers who give birth at advanced maternal ages are at higher risk of giving birth to a LBW child (Goisis, 2015). In other words, the social advantages of older mothers might compensate for or even outweigh the health risks associated with advanced age (Stein and Susser, 2000). For this reason, we analyse both the socio-demographic and health characteristics of mothers based on their age when they gave birth. Some of the covariates are identical or highly similar across the cohorts (e.g., social class), others are measured differently (e.g., the mother's education), and others have been collected in some of the cohorts and not in others (e.g., information on complications during pregnancy was collected in the MCS only). For each cohort study, we use all of the available and relevant variables. The variables are listed in Table 1.

We considered including additional covariates. For example, we adjusted for the region of residence as it might have captured variation in the quality of health services available where the mother gave birth, but the results were largely unchanged. Adjusting for mother's ethnicity in the MCS (in the other cohorts, the samples were predominantly white) also did not change the results.

\section{Statistical analyses}

The first step consists of comparing the socio-demographic characteristics, the health behaviours, and the health characteristics of the mothers by their age when they gave birth in the four cohort studies. The aim of this step is to show whether and how the profiles of the mothers who gave birth at advanced ages changed over time.

Next, in order to analyse the association between advanced maternal age and LBW, we estimate a series of logistic regression models. Since some of the variables had missing values, we have used multiple imputations to create 20 filled-in datasets for each birth cohort using the multivariate imputation by the chained equation method in Stata 13. Appendix Table A1 shows the sample size increase we obtain by imputing 
the datasets. The results on the non-imputed dataset are qualitatively similar. We impute all of the variables with the exception of the dependent variable (LBW) and birth order. ${ }^{\mathrm{v}}$ Using the imputed datasets we estimate, for each birth cohort separately, a series of models that include varying sets of covariates. Analyses for the MCS are conducted using sample weighting and accounting for the complex survey design. All analyses are conducted in Stata 13.

We begin by exploring the association between maternal age and LBW using a sample including all birth orders. We estimate four model specifications, illustrated in equations (1) to (4):

(2) $\operatorname{Logit}(Y)=\alpha+\beta_{1} M A B+\beta_{2}$ CHILDEM $+\beta_{3}$ MATSOCIODEM

(3) $\operatorname{Logit}(Y)=\alpha+\beta_{1} M A B+\beta_{2} C H I L D E M+\beta_{3} M A T H E A L T H$

(4) $\operatorname{Logit}(Y)=\alpha+\beta_{1} M A B+\beta_{2}$ CHILDEM $+\beta_{3}$ MATSOCIODEM $+\beta_{4}$ MATHEALTH

where $\mathrm{Y}$ is child health (LBW), MAB are categories of maternal age at birth (maternal age 25-29 is the reference category), CHILDEM are cohort members' basic demographic characteristics (sex, multiplicity, and birth order ${ }^{\mathrm{vi}}$ ), MATSOCIODEM are the mothers' or the families' socio-demographic characteristics (e.g., level of education, marital status at the time of birth), and MATHEALTH is the mothers' health before or during pregnancy (e.g., previous miscarriages, C-section delivery). Model 1 is the baseline model. In Model 2 we adjust for the mothers' or the families' socio-demographic characteristics, and in Model 3 we adjust for the mothers' health before or during pregnancy. Finally, Model 4 is a fully adjusted model. The models that include adjustments for covariates are only partially comparable across cohorts, since in each study we adjust for a different set of covariates.

As a second step, we estimate the models on first-order births only. We estimate the same four models, although this time we do not control for birth order. Although excluding higher-order births comes at the cost of sample size, first-order births represent an important subsample. Existing studies have shown that the negative association between advanced maternal age and child health is particularly pronounced for first-order births (Lisonkova et al., 2010). Moreover, among the more recent cohorts the mothers who gave birth to their first child at an advanced age are 
likely to be particularly selected and advantaged (Martin, 2004b), and their characteristics may have more than compensated for the increased health risks associated with giving birth at an advanced age. Therefore, if a secular decline in the association between advanced maternal age and LBW exists, we expect to find that it is more pronounced for first-order births than for all births.

Finally, in order to directly measure differences over time, we pool the data for the 1958 NCDS and the 2001 MCS studies (i.e., the least recent and the most recent birth cohorts), and estimate a pooled model that includes the baseline variables, as well as the interactions of the baseline variables with the MCS indicator variables. ${ }^{\text {vii }}$ Of central interest in the pooled model is the coefficient estimate and the statistical significance of the interaction of the 40+ age group with an MCS indicator. As with the analyses on each birth cohort separately, we obtain estimates for a sample that includes all order births, and for a second sample that includes first-order births only.

\section{Results}

\section{Descriptive associations}

Table 2 shows the distribution of all births and first-order births by maternal age categories. We can see a marked change across the cohorts. The percentage of births to mothers under age 20 remained fairly stable across the birth cohorts, while the percentage of births to mothers aged 20-24 halved. As expected, important changes occurred in the distribution of births at older maternal ages. The percentage of births (first births in particular) at ages 30-34 and 35-39 increased markedly across birth cohorts. For example, 3\% of first births in 1958 were to mothers aged 35-39, compared to $9 \%$ in 2001 . The percentage of all order births to mothers aged 40 or older remained fairly stable across the birth cohorts; although it increased for firstorder births, it continues to be low in absolute terms, at $1 \%$ in the most recent cohort. These changes across cohorts reflect the process of childbearing postponement documented in the UK and other European countries since the 1970s (Sobotka, 2004).

Table 2 also shows that the overall prevalence of LBW babies who were born alive remained fairly stable across birth cohorts. This may be because (very) LBW children 
have higher survival rates today than they did in the past (Hack et al., 1995). This suggests that the more recent cohorts (1992 and 2001) include LBW children who were excluded in the less recent cohorts (1958 and 1970). Our estimates therefore tend to be conservative.

Figure 1 shows the unadjusted association between LBW and maternal age by birth cohort for all births. It is U-shaped for all of the cohort studies. The pattern we observe among young mothers is in line with our expectations given the socioeconomic disadvantages of this group (McLanahan, 2004). The higher rates of LBW we observe among older mothers are consistent with the medical literature on the adverse health outcomes of fertility postponement (Bewley et al., 2005). The pattern for first births is qualitatively similar, but with some inconsistencies in the shape of the association, which may be due to the small sample size (Appendix Figure A1).

Figure 2 and Figure 3 show the distribution of selected mothers' socio-demographic characteristics and health behaviours across the cohorts. Consistent with expectations, we find that the older mothers who gave birth in 1992 and 2001 were more advantaged than the younger mothers. For example, Figure 2 shows that among the mothers who gave birth in 1958 and 1970, the percentage of older mothers who belonged to a household of a high social class was lower than that of the mothers who gave birth in their mid-twenties. The reverse was true for the mothers who gave birth in 1992 and 2001. The results for other socio-economic indicators are qualitatively similar. For example, while in all of the cohort studies the older mothers were more likely to have been married when they conceived or gave birth than the younger mothers, the differences between the older and the younger mothers were much more pronounced in the more recent cohorts (see Appendix Table A2).

Figure 3 shows that there was no age gradient in smoking during pregnancy among the older cohorts, whereas the older mothers who gave birth in 1992 or 2001 were far less likely to have smoked during pregnancy than the younger mothers. The percentage of the mothers who used antenatal care for the first time after 12 weeks of pregnancy declined steadily across the cohorts (Appendix Table A2); on average, the older mothers were more likely than the younger mothers to have used antenatal care early in all of the cohorts. This pattern is not, however, entirely monotonic, as the mothers in the oldest age group were marginally less likely to have used antenatal 
care early than the mothers in the middle-aged group. However, the age gradient is clearer when we look at first births only. In the 1992 and 2001 cohorts, the older mothers were more likely than the younger mothers to have been drinking heavily during pregnancy, although the differences in 2001 were smaller than they were in 1992 (Appendix Table A2).

The results suggest that across the cohorts, the differences in the profiles of the mothers who gave birth at ages 40 and above and those of the mothers who gave birth in their early/mid-twenties grew, and became increasingly associated with socioeconomic advantages and better health behaviours during pregnancy. In addition, the secular changes in the profiles of the older mothers appear to be more pronounced when we look at the characteristics of first-time mothers (Appendix Table A2).

Figure 4 shows the results for C-section deliveries. On average and in all of the cohorts, the older mothers were more likely than the younger mothers to have had a C-section delivery. Additional results (Appendix Table A3) also show that older mothers were more likely to have experienced stillbirths/miscarriages and complications during pregnancy. For example, compared to the younger mothers, the older mothers were more likely to have experienced foetal distress during labour in the 1958 cohort study, an abnormal heart rate during delivery in the 1970 cohort study, gestational hypertension in the 1992 cohort study, and any complication during pregnancy in the 2001 cohort study (Appendix Table A3).

These results suggest that in all of the cohorts the older mothers were at higher risk of complications during pregnancy and delivery. Because only the prevalence of stillbirths and of C-sections were collected in each cohort study, it is more difficult to relate the findings for health characteristics across the cohorts than the findings for socio-demographic characteristics. Nonetheless, based on these two indicators, compared to the previous cohorts the mothers who gave birth at ages 40 and above in the 2001 cohort were only marginally less likely than the mothers who gave birth in their early/mid-twenties to have experienced obstetric issues.

\section{Regression results}

Figure 5 shows the odds ratios for low birth weight among mothers aged 40 and above, relative to the ratios among mothers aged 25-29, from Model 1 (the baseline 
Model). Table 3 shows the parameter estimates for mothers aged 40 and above for Models 1-4 for all births and for first-order births. Appendix Table A4 and Appendix Table A5 show the full model results for, respectively, for all births and for first-order births.

As we can see in Figure 5, Model 1 (baseline model) for all births and first-order births shows a secular decline in the association between advanced maternal age and LBW. Appendix Figure A2 shows very similar results when maternal ages 20-24 are used as the reference category.

Table 1 shows that for all order births in Model 1 the mothers who were aged 40 and above at the time of birth in the 1958, 1970, and 1992 cohort studies had significantly higher odds of giving birth to a LBW child than the mothers in the reference category (25-29). The mothers who gave birth in the 2001 cohort had higher odds of having a LBW child, but the odds ratio was smaller than the odds ratio in the other cohort studies, and was not statistically significant. The Model 1 results for first-order births reveal that the mothers who were aged $40+$ when they gave birth to their first child in 1958 had significantly higher odds of having a LBW child than the mothers in the reference category (25-29). The mothers who were aged 40+ when they gave birth in 1970 had higher odds of having a LBW child than the mothers aged 25-29, but the differences are not statistically significant, which could be because the small number of first births at ages 40+ result in an imprecise estimation of the parameters. The mothers who were aged 40+ when they gave birth in 1992 or 2001 did not have significantly higher odds of having a LBW child than the mothers in the reference category. As we expected, the secular decline is more pronounced when we look at first-order births only. As we can see in the descriptive results, the mothers who gave birth to their first child at an advanced age in 1992 and 2001 are particularly selected and advantaged, and their characteristics could more than compensate for the increased health risks associated with giving birth at an advanced age.

The upper part of Table 3 shows how the odds ratios for all order births among the mothers aged 40+ changes when we adjust for socio-demographic and health characteristics. The results for Model 2 show that the adjustment for sociodemographic characteristics (variables listed in Table 1) results in opposite changes for the mothers in the 1958 and 1970 studies on the one hand, and for the mothers in 
the 1992 and 2001 cohort studies on the other. The odds ratio decreases among the mothers aged 40+ of the 1958 and 1970 cohort studies. In contrast, among the mothers aged 40+ in the 1992 and 2001 cohorts studies, the odds ratio increases, and for the mothers in the 2001 study the odds ratio becomes statistically significant and reaches levels close to those observed in the baseline model of the older cohorts. The results suggest that the secular decline in the association between advanced maternal age and LBW is at least partially explained by the more advantaged profile of the women who recently gave birth at an advanced maternal age. The results for Model 3 show that adjustment for health characteristics reduces the odds ratios in all of the birth cohorts to a similar extent. In particular, for the 1992 cohort study the odds ratio for the mothers aged $40+$ is no longer statistically significant. This suggests that in this cohort the older mothers faced a higher risk of having a LBW child because of increased health complications that were not compensated for by the advantaged profiles of older mothers to the same extent as they were in the more recent 2001 cohort. Conversely, after health variables are adjusted for in the 1958 and 1970 cohort studies, the odds ratios are reduced, but are still statistically significant. The results for Model 4 (fully adjusted for both socio-demographic and health characteristics) show that only the odds ratio for the mothers aged 40+ in the 1958 cohort is statistically significant. In the fully adjusted model, the secular decline is attenuated compared to Model 1, but not entirely eliminated.

The lower part of Table 3 shows that the odds ratios for the mothers aged $40+$ for first-order births changes when the socio-demographic and health characteristics are adjusted for. The adjustment for socio-demographic variables results in a small increase compared to the baseline model of the odds ratio for the mothers aged $40+$ in the 1958 cohort; for these mothers in the 1970 cohort, the odds ratio decreases compared to the baseline model. For the mothers aged 40+ in the 1992 and 2001 cohort studies, the odds ratios increases. However, for the mothers aged $40+$ in the 2001 study, the odds ratio for first-order births, unlike for births of all orders, does not reach statistical significance and the levels observed in the unadjusted model of the older cohorts. The remaining differences can be attributed to the mothers' unobserved characteristics and/or changes in the medical context surrounding childbearing (e.g., introduction of prenatal screening and pharmacological advancements for treating complicated pregnancies). Adjustments for health variables produce changes similar 
to those observed for all order births, since in all of the cohort studies they attenuate the association between giving birth at an advanced maternal age and the odds of having a LBW child. In the 1992 and 2001 cohort studies, the odds ratio for the mothers aged $40+$ become smaller than one. The odds ratios for the mothers aged $40+$ in Model 4 (fully adjusted) are lower compared to the baseline values, but the secular decline is not eliminated or reduced.

The results suggest that the increased odds of having a LBW child among the mothers aged $40+$ in the older cohorts are at least partially (1958 cohort) or entirely (1970 cohort) explained by their relatively high health risks and their socio-economic profiles, which are not markedly more advantaged than those of younger mothers. The results also indicate that in a contemporary context mothers who give birth at advanced maternal ages are at lower risk of giving birth to a LBW child than in the past, despite having a higher risk of pregnancy complications. This finding reinforces the hypothesis that the secular decline should be attributed to changes in mothers' characteristics and obstetric practices, which can compensate for and manage the health risks associated with giving birth at advanced maternal ages.

As a final step, we estimate the baseline model pooling data from the oldest (1958) and the most recent (2001) cohort studies. The aim is to directly compare differences across these cohorts and the secular change in the association between advanced maternal age and LBW. Appendix Table A6 reports the main coefficients of interest. The pooled model includes interaction effects between the 2001 cohort and maternal age variables. The results are in line with those in Figure 5. For all order births, the odds ratio of the interaction of the 40+ age group with the MCS indicator is substantially below one (0.72), but is statistically insignificant. When we look at firstorder births only, we can see that the odds ratio is even smaller than the odds ratio for all order births (0.45), but again it fails to reach statistical significance. However, when we look at the results for first-order births with reference category 20-24 (Appendix Table A6), we observe differences that are statistically significant at the $10 \%$ level. 


\section{Conclusions}

The association between maternal age and child well-being remains a highly controversial issue, as maternal ages at birth continue to increase across the developed world. The existing literature has not reached a consensus on the question of to what extent giving birth at advanced maternal ages should be avoided. In this literature and in the current debates, one issue that has not received attention until now is the question of whether the association between advanced maternal age and child wellbeing is systematically changing over time. A secular change in the association between advanced maternal age and child health may occur as a result of changes in the characteristics of older mothers, as well as of improvements in medical and obstetric practices. This is the first study that has investigated the question of whether the association between advanced maternal age and LBW has changed over time. We analysed four large UK birth cohort studies, and found that, across successive cohorts, but particularly when the 2001 cohort was compared with the 1958 cohort, giving birth at an advanced maternal age (i.e., at age 40 or above) was less likely to be associated with giving birth to a low birth weight child. The secular decline in the association between advanced maternal age and birth weight was more pronounced for first-order births. In all of the cohorts older mothers tended to be more advantaged than their younger counterparts, but this gap widened considerably over successive cohorts. Still, in all of the cohorts studied, older mothers were at higher risk than younger mothers of having complicated pregnancies and deliveries.

Adjusting the association between advanced maternal age and low birth weight for either socio-economic characteristics or health of the mother proved to be very helpful for understanding the process through which the association declined over birth cohorts. When we included in the models adjustments for the families' and the mothers' socio-demographic characteristics, the risk of low birth weight associated with advanced maternal age increased markedly in the more recent cohort; close to the levels observed in the older cohorts. This shows that an important mechanism through which the risk of low birth weight has declined among older mothers is that older mothers are becoming more socio-economically advantaged over time, and this accumulation of social resources offsets the otherwise negative effect of advanced maternal age on birth weight. When we included in the models an adjustment for the mothers' health, the risk of low birth weight associated with advanced maternal age 
decreased in all of the cohorts. But the health-adjusted results in particular contribute to our conclusion that the increased health risks experienced by the mothers who gave birth at advanced maternal ages in the 1958 and 1970 cohort studies (and, to some extent, in the 1992 cohort study) - which were not compensated for by the increased socio-economic status of the older mothers, as was the case in the more recent cohort - are important mechanisms for explaining the increased odds of having a LBW child among this group. Finally, in the fully adjusted models, the cross-cohort differences were attenuated compared to the baseline model, but were not entirely eliminated. A possible explanation for the remaining secular trend is that there were changes in the epidemiological context. Indeed, it is plausible to expect that having access to modern obstetric care could make the risks associated with giving birth at an advanced maternal age more manageable than they were in the past. Although the data do not allow us to test for the latter effects directly, we think it is reasonable to hypothesise that the explanation for the secular decline lies at the intersection of the changes in the mothers' characteristics and in the surrounding epidemiological context. In the UK, important advancements in neonatal care were introduced after the 1970s, and these improvements may have made easier than it was in the past for women to manage the risks associated with giving birth at an advanced age.

This research has limitations. First, sample size issues meant that some parameters were not precisely estimated, especially in the analyses of first-order births. Nonetheless, the analyses of all births, which were less affected by problems with sample size, showed a clear secular decline in the association between advanced maternal age and LBW. Sample size issues also precluded analyses that distinguished between children with a very low birth weight $(<1500 \mathrm{~g})$ and those with a moderately low birth weight (1500 - 2500 g). It was not possible to account for gestational age, as this information was missing or not reliable in $10 \%$ and $18 \%$ of cases in, respectively, the 1958 and 1970 analytical samples used in this analysis. Nonetheless, LBW is considered an important marker of neonatal outcomes, as many existing studies have found that LBW, for both babies born preterm and at term, is associated with important markers measured at different stages of the life course (Black et al., 2007, Richards et al., 2001, Hack et al., 1995). Second, we were unable to establish to what extent secular changes in the association between advanced maternal age and LBW were driven by changes in the overall epidemiological context. Third, this study 
focuses on the UK only, and it is unclear to what extent the results are generalisable to other countries. We think it is likely that we would observe similar results in other developed countries in which the trends in the postponement of childbearing and the changes in the epidemiological context surrounding childbearing are similar to those in the UK. To overcome these limitations, it would be necessary to conduct similar analyses using different data, and for countries that have-and, importantly, for countries that have not-experienced improvements in the context.

Despite the limitations, these findings have implications that are relevant for both theory and research. First, the intersection of the changing selection into older maternal ages and the improvements in the context over time might modify the association between maternal age and child well-being. As a consequence, the direction and the strength of the association between maternal age and child outcomes are tied to a specific population and point in time. This indicates that studies that investigate the association between maternal age and child well-being must reflect on and situate the meaning of maternal age in the context, the groups, and the historical period under consideration; while paying particular attention to the selection process that underlies the individual differences in the timing of childbearing (Geronimus, 1996). Second, since the link between advanced maternal age and LBW has loosened over time, the children of older mothers are at lower risk of poor health outcomes today than they were 50 years ago. This argument is further supported by evidence showing that the negative association between having a low birth weight and subsequent well-being has declined across cohorts (Goisis et al., 2015). It therefore appears that, compared to previous generations, today's children of older mothers are not only less likely to be born LBW; when they are born LBW, the negative consequences are less severe.

This is the first study that has investigated and documented the secular changes in the association between advanced maternal age and child health around the time of birth. This topic remains controversial, and our results suggest that the period under consideration might be an important source of variation between studies, which needs to be taken into account both before and after adjustment for covariates. Our results show that across successive birth cohorts, the association between advanced maternal age and low birth weight became progressively weaker, and is negligible, both statistically and substantively, for the most recent birth cohort. The decline in the 
association is at least partially explained by the socio-economic advantages of older mothers in the more recent cohorts. The results suggest that if selection into older maternal ages had not changed in the more recent cohorts, advanced maternal age would still have been associated with a higher risk of LBW. Future research should enrich our understanding of these time trends by replicating the analyses of this study through the investigation of other markers of child outcomes, geographical contexts, and time periods. 
Acknowledgements section We would like to thank the 1958, 1970, and Millennium Cohort Study families for their time and co-operation, as well as the Centre for Longitudinal Studies at the Institute of Education. The cohort data are funded by the UK Economics and Social Research Council. The cohort data are deposited in the UK Data Archive. We are extremely grateful to all the families who took part in the ALSPAC study, the midwives for their help in recruiting them, and the whole ALSPAC team, which includes interviewers, computer and laboratory technicians, clerical workers, research scientists, volunteers, managers, receptionists and nurses. The UK Medical Research Council and the Wellcome Trust (Grant ref: 102215/2/13/2) and the University of Bristol provide core support for ALSPAC. This publication is the work of the authors (names not included as journal requires this version of the manuscript to be blind) will serve as guarantors for the contents of this paper. 


\section{References}

ALDOUS, M. B. \& EDMONSON, M. B. 1993. Maternal Age at First Childbirth and Risk of Low Birth Weight and Preterm Delivery in Washington State. The Journal of the American Medical Association, 270, 2574-2577.

BARKAN, S. E. \& BRACKEN, M. B. 1987. Delayed childbearing: no evidence for increased risk of low birth weight and preterm delivery American Journal of Epidemiology, 125, 101-109.

BERKOWITZ, G. S., SKOVRON, M. L., LAPINSKI, R. H. \& BERKOWITZ, R. L. 1990. Delayed Childbearing and the Outcome of Pregnancy. New England Journal of Medicine, 322, 659-664.

BEWLEY, S., DAVIES, M. \& BRAUDE, P. 2005. Which career first? The most secure age for childbearing remains 20-35. British Medical Journal, 331, 588589

BIANCO, A., STONE, J., LYNCH, L., LAPINSKI, R., BERKOWITZ, G. \& BERKOWITZ, R. L. 1996. Pregnancy outcome at age 40 and older. Obstetrics \& Gynecology, 87, 917-922.

BILLARI, F. C., KOHLER, H.-P., ANDERSSON, G. \& LUNDSTROM, H. 2007. Approaching the limit: long-term trends in late and very late fertility. Population and development review, 33, 149-170.

BLACK, S. E., DEVEREUX, P. J. \& SALVANES, K. G. 2007. From the Cradle to the Labor Market? The Effect of Birth Weight on Adult Outcomes. The Quarterly Journal of Economics, 122, 409-439.

BOARDMAN, J. D., POWERS, D. A. \& HUMMER, R. A. 2002. Low Birth Weight, Social Factors, and Developmental Outcomes Among Children in the United States. Demography, 39, 353-368.

BOYD, A., GOLDING, J., MACLEOD, J., LAWLOR, D. A., FRASER, A., HENDERSON, J., MOLLOY, L., NESS, A., RING, S. \& DAVEY SMITH, G. 2013. Cohort Profile: The 'Children of the 90s' - the index offspring of the Avon Longitudinal Study of Parents and Children. International Journal of Epidemiology, 42, 111-127.

BRAY, I., GUNNELL, D. \& DAVEY SMITH, G. 2006. Advanced paternal age: How old is too old? Journal of Epidemiology and Community Health, 60, 851-853.

CAROLAN, M. 2003. The graying of the obstetric population: Implications for the older mother. Journal of Obstetric Gynecologic and Neonatal Nursing, 32, 1927.

CAROLAN, M. \& FRANKOWSKA, D. 2011. Advanced maternal age and adverse perinatal outcome: A review of the evidence. Midwifery, 27, 793-801.

CUNNINGHAM, F. G. \& LEVENO, K. J. 1995. Childbearing among Older Women - The Message is Cautiously Optimistic. New England Journal of Medicine, 333, 1002-1004.

DUNN, P. M. 2006. The birth of perinatal medicine in the United Kingdom. Seminars in Fetal and Neonatal Medicine, 11, 386-397.

FERTIG, A. R. 2010. Selection and the effect of prenatal smoking. Health Economics, 19, 209-226.

FIGLIO, D., GURYAN, J., KARBOWNIK, K. \& ROTH, J. 2014. The Effects of Poor Neonatal Health on Children's Cognitive Development. American Economic Review, 104, 3921-55. 
FRETTS, R. C., SCHMITTDIEL, J., MCLEAN, F. H., USHER, R. H. \& GOLDMAN, M. B. 1995. Increased Maternal Age and the Risk of Fetal Death. New England Journal of Medicine, 333, 953-957.

GERONIMUS, A. T. 1996. Black/white differences in the relationship of maternal age to birthweight: A population-based test of the weathering hypothesis. Social Science \& Medicine, 42, 589-597.

GOISIS, A. 2015. How are children of older mothers doing? Evidence from the U.K. Biodemography and Social Biology, Forthcoming.

GOISIS, A., OZCAN, B. \& MYRSKYLÄ, M. 2015. The negative association between low birth weight and cognitive ability is decreasing: evidence from three UK birth cohorts. British Society for Population Studies. Leeds.

HACK, M., KLEIN, N. K. \& TAYLOR, H. G. 1995. Long-Term Developmental Outcomes of Low Birth Weight Infants. The Future of Children, 5, 176-196.

HANSEN, J. P. 1986. Older maternal age and pregnancy outcome: a review of the literature. Obstetrical \& Gynecological Survey, 41, 726-42.

HANSEN, K. 2008. Millennium Cohort Study First, Second and Third Surveys: A Guide to the Datasets. London: Centre for Longitudinal Studies, Institute of Education, University of London.

HAWKES, D., JOSHI, H. \& WARD, K. 2004. Unequal entry to Motherhood and Unequal Starts in Life: Evidence form the First Survey of the UK Millenium Cohort. CLS Cohort Studies Working Paper London: Centre for Longitudinal Studies.

HEFFNER, L. J. 2004. Advanced Maternal Age -- How Old Is Too Old? N Engl $J$ Med, 351, 1927-1929.

JEFFERIS, B. J., POWER, C. \& HERTZMAN, C. 2002. Birth weight, childhood socioeconomic environment, and cognitive development in the 1958 British birth cohort study. BMJ, 325, 305.

JOLLY, M., SEBIRE, N., HARRIS, J., ROBINSON, S. \& REGAN, L. 2000. The risks associated with pregnancy in women aged 35 years or older. Human Reproduction, 15, 2433-2437.

KIRZ, D. S., DORCHESTER, W. \& FREEMAN, R. K. 1985. Advanced maternal age: the mature gravida. American Journal of Obstetrics and Gynecology, 152, 7-12.

KOLENIKOV, S. 2010. Resampling Variance Estimation for Complex Survey Data. The Stata Journal, 10, 165-199.

LISONKOVA, S., JANSSEN, P. A., SHEPS, S. B., LEE, S. \& DAHLGREN, L. 2010. The effect of maternal age on adverse birth outcomes: does parity matter. J Obstet Gynaecol Can, 32, 541-548.

MARTIN, S. P. 2004b. Women's education and family timing: outcomes and trends associated with age at marriage and first birth. In: NECKERMAN, K. M. (ed.) Social Inequality. New York: Russell Sage Foundation.

MCLANAHAN, S. 2004. Diverging Destinies: How Children Are Faring Under the Second Demographic Transition. Demography, 41, 607-627.

MILLS, T. A. \& LAVENDER, T. 2011. Advanced maternal age. Obstetrics, Gynaecology \& Reproductive Medicine, 21, 107-111.

MYRSKYLÄ, M. \& FENELON, A. 2012. Maternal Age and Offspring Adult Health: Evidence From the Health and Retirement Study. Demography, 49, 1231-57.

PRIOUX, F. 2005. Late fertility in Europe: some comparative and historical data. Revue D Epidemiologie Et De Sante Publique, 53, 2S3-2S11. 
REICHMAN, N. 2005. Low birth weight and school readiness. The Future of Children, 15, 91-116.

RICHARDS, M., HARDY, R., KUH, D. \& WADSWORTH, M. E. 2001. Birth weight and cognitive function in the British 1946 birth cohort: longitudinal population based study. Bmj, 322, 199-203.

SEIDMAN, D. S., EVER-HADANI, P., STEVENSON, D. K., SLATER, P. E., HARLAP, S. \& GALE, R. 1988. Birth order and birth weight reexamined. Obstetrics \& Gynecology, 72, 158-162.

SOBOTKA, T. 2004. The postponement of Childbearing and Low Fertility in Europe, Amsterdam, Dutch University Press.

STEIN, Z. \& SUSSER, M. 2000. The risks of having children in later life. BMJ, 320, 1681-1682.

TATE, A. R., DEZATEUX, C., COLE, T. J. \& DAVIDSON, L. 2005. Factors affecting a mother's recall of her baby's birth weight. International Journal of Epidemiology, 34, 688-695.

TOUGH, S., NEWBURN-COOK, C., JOHNSTON, D. W., SVENSON, L. W., ROSE, S. \& BELIK, J. 2002. Delayed Childbearing and Its Impact on Population Rate Changes in Lower Birth Weight, Multiple Birth, and Preterm Delivery. Pediatrics, 109, 399-403.

ZIADEH, S. \& YAHAYA, A. 2001. Pregnancy outcome at age 40 and older. Archives of gynecology and obstetrics, 265, 30-33. 


\section{Figures and Tables}

\section{Figures}

Figure 1: \% LBW by maternal age categories and birth cohort, all births

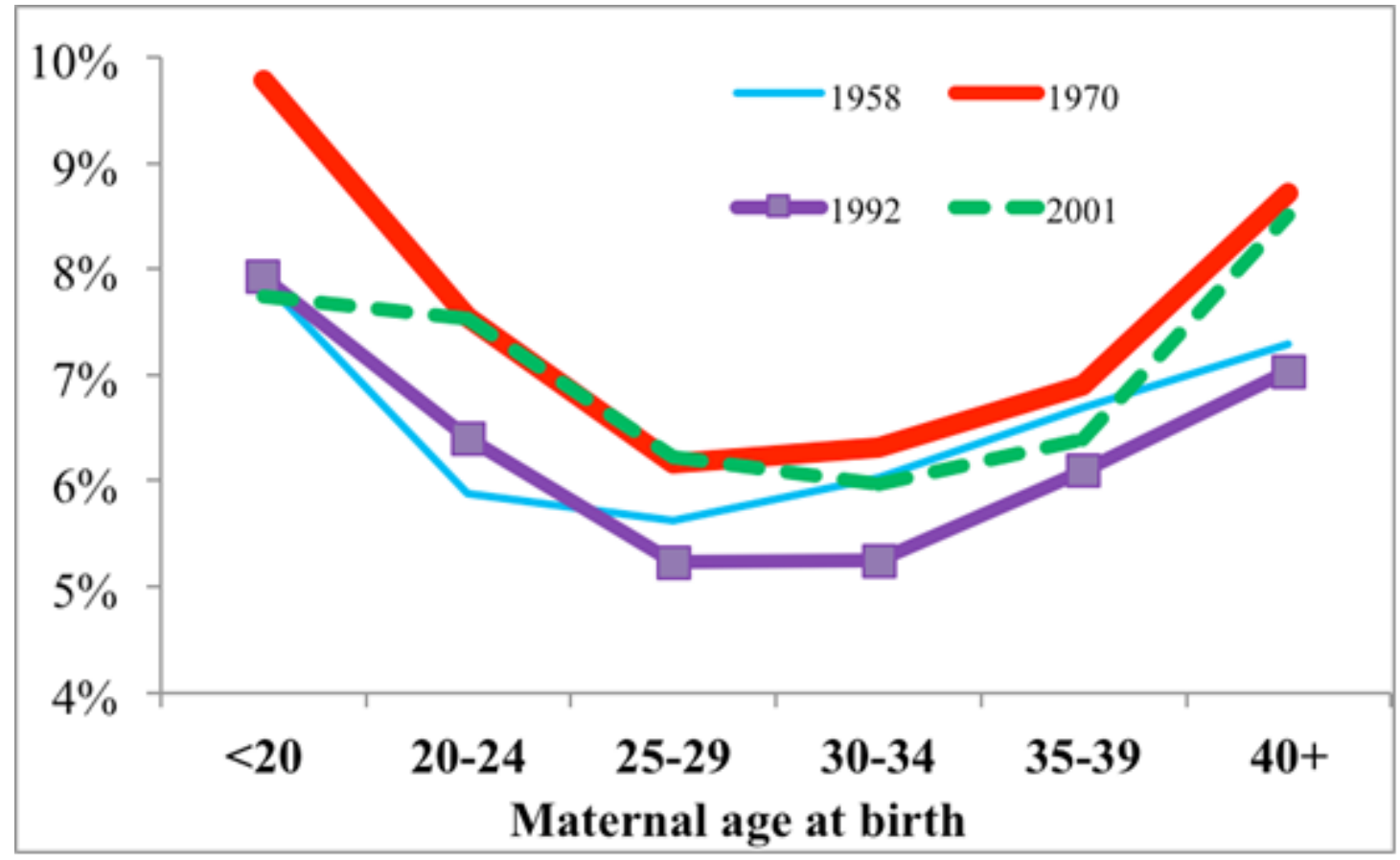


Figure 2: Percentage of mothers of a high household social class, by maternal age at birth and birth cohort

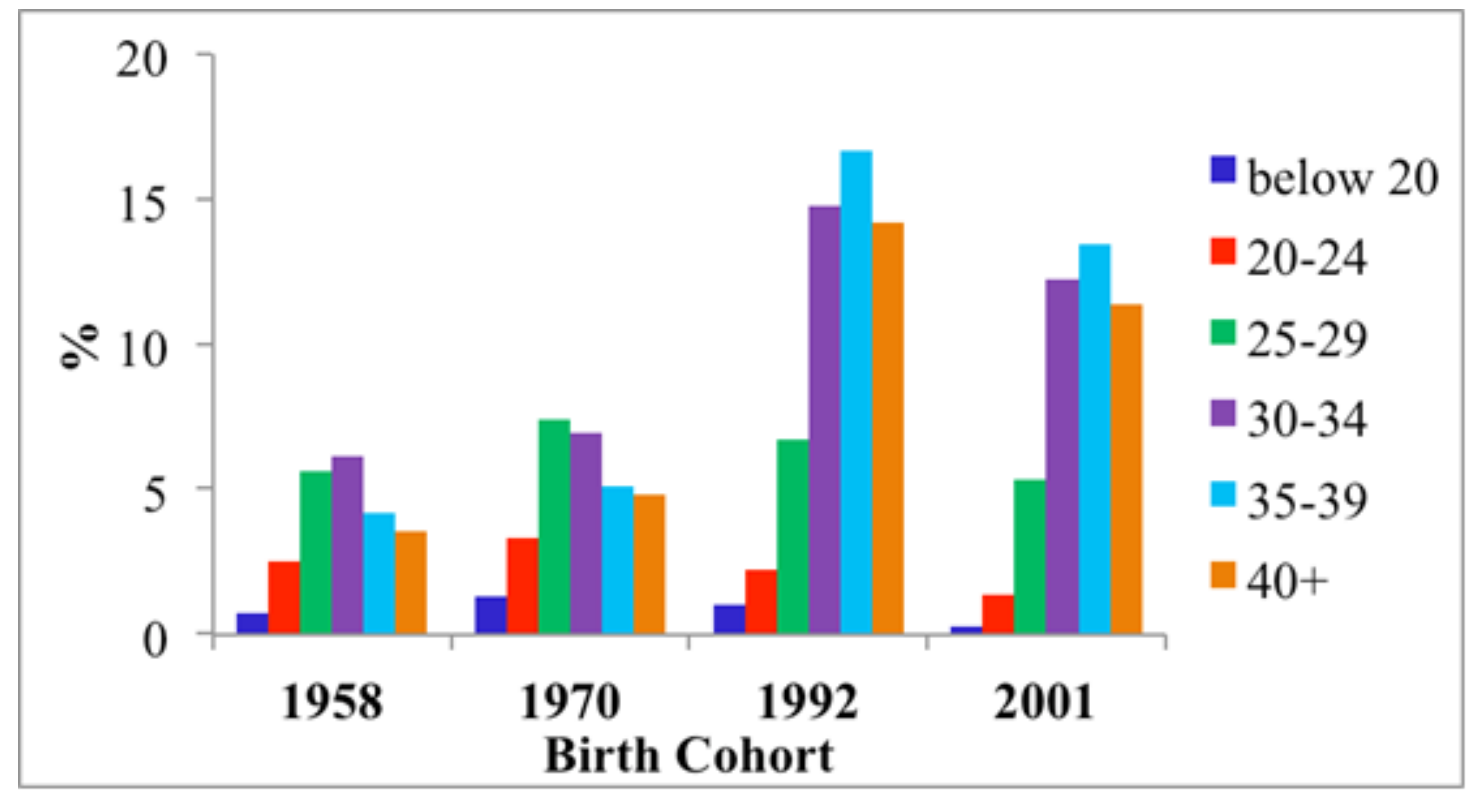

Figure 3: Percentage of mothers who smoked during pregnancy, by maternal age at birth and birth cohort

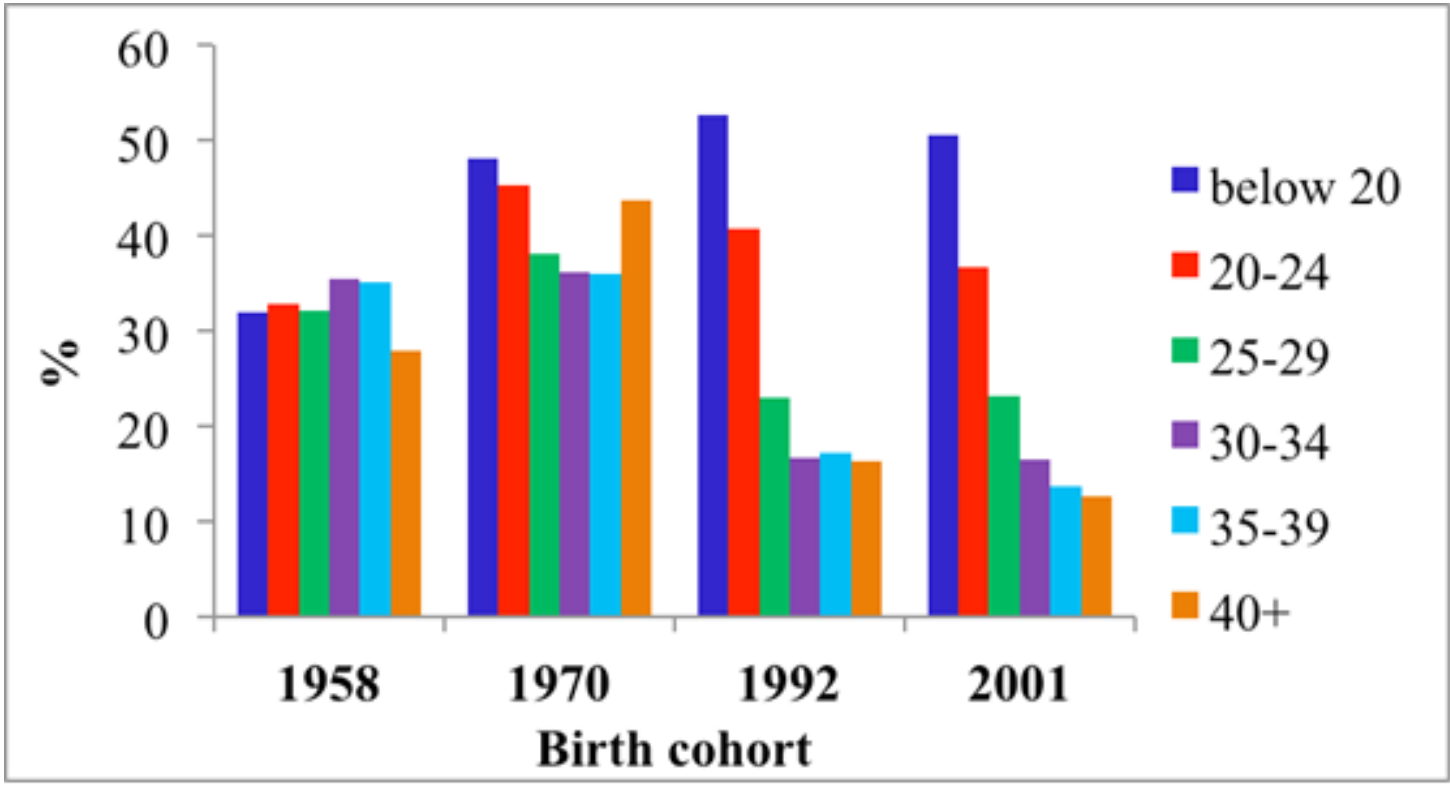


Figure 4: Percentage of mothers who delivered by C-section, by maternal age at birth and birth cohort

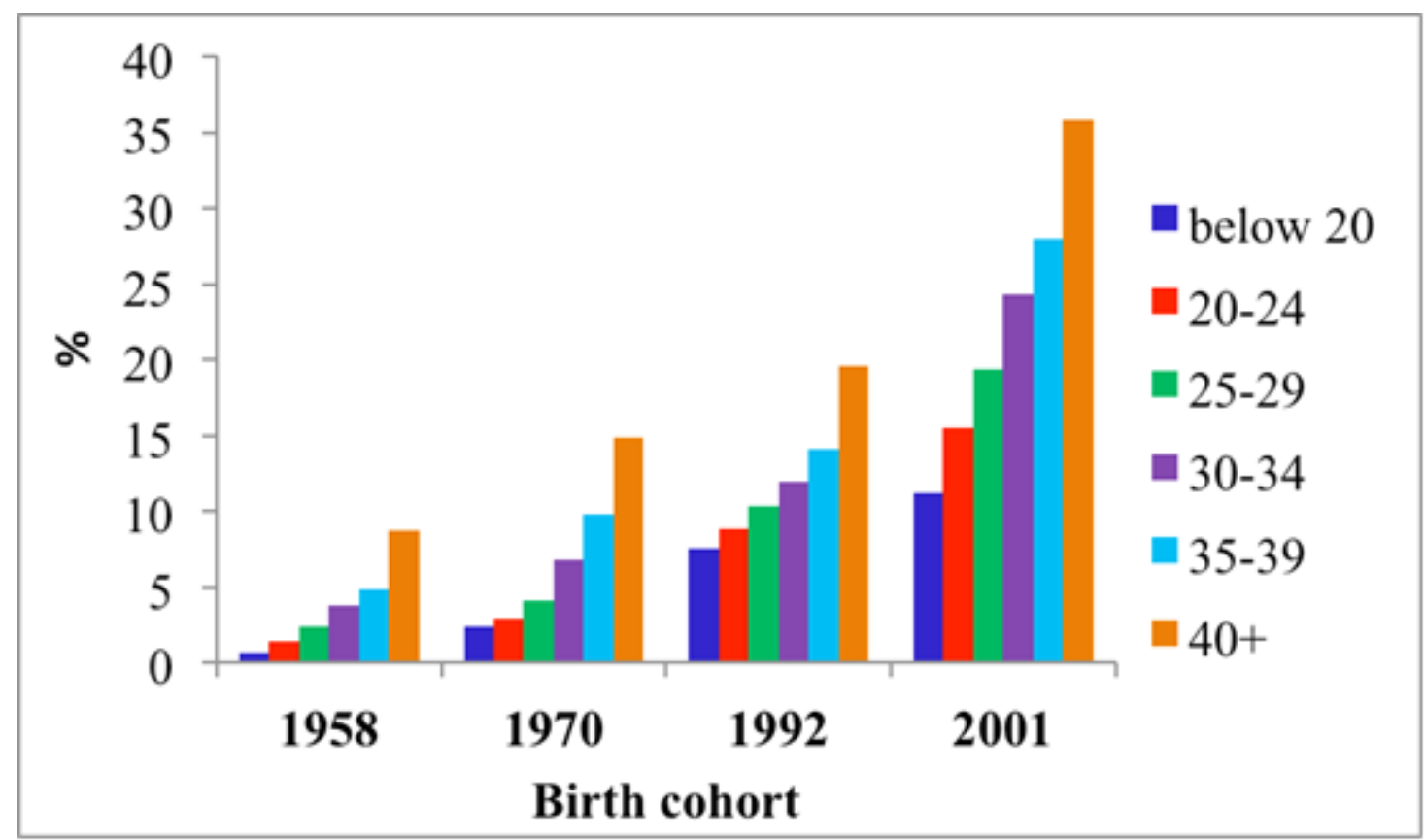

Figure 5: Odds ratios of LBW for mothers aged 40+ for all births and first-order births, by birth cohort (Model 1)

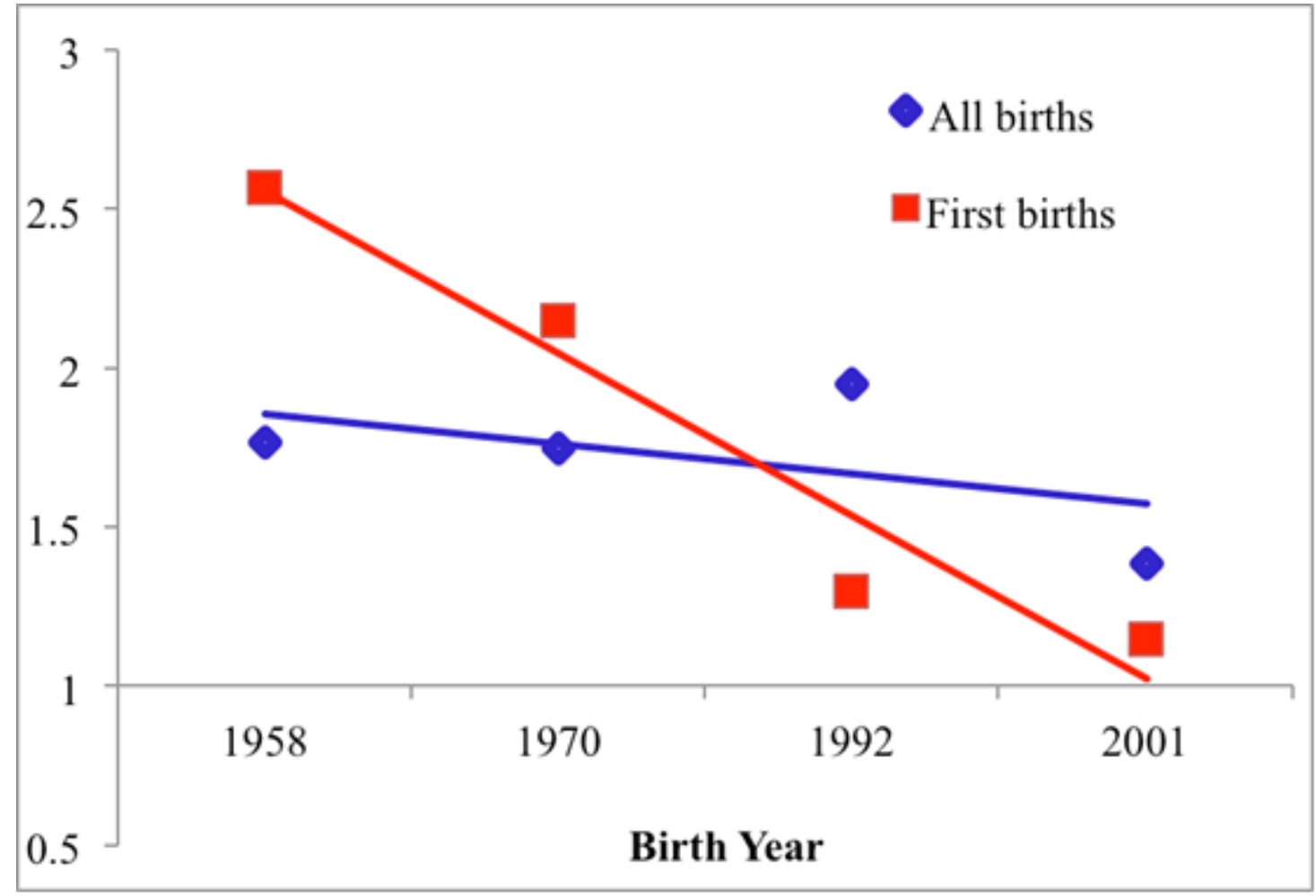




\section{Tables}

Table 1: Description of covariates used in the analyses and collected at Sweep 1 for each cohort study

$\begin{array}{llll}\text { NCDS } & \text { BCS } & \text { ALSPAC } & \text { MCS } \\ 1958 & 1970 & 1992 & 2001\end{array}$

\section{Basic variables}

Maternal age at birth

Parity

Multiple birth

Gender of cohort child

\section{Socio-demographic variables}

Social class RGSC classification (1958, 1970: father; 1992, 2001: highest level in the household)

Mother's education

Mother was working before birth

Household income

Overcrowded household

Marital status (1958, 1992, 2001: at birth; 1970: at conception)

Mother smoked during pregnancy

Mother's height

Antenatal care after 12 weeks of pregnancy

Mother drank during pregnancy

Pregnancy was planned

\section{Health variables}

Mother had previous stillbirths

Mother had miscarriages

C-sections delivery

Foetal distress during pregnancy

Abnormality

Labour lasted more than 24 hours

Cohort child had abnormal heart rate during delivery

Mother had proteinuria

Number of hospital discharges during pregnancy

Mother in good health up to start of pregnancy

Gestational hypertension

Complications during pregnancy

$\begin{array}{llll}\sqrt{ } & \sqrt{ } & \sqrt{ } & \sqrt{ } \\ \sqrt{ } & \sqrt{ } & \sqrt{ } & \sqrt{ } \\ \sqrt{ } & \sqrt{ } & \sqrt{ } & \sqrt{ } \\ \sqrt{ } & \sqrt{ } & \sqrt{ } & \sqrt{ }\end{array}$

$\begin{array}{llll}\sqrt{ } & \sqrt{ } & \sqrt{ } & \sqrt{ } \\ \sqrt{ } & \sqrt{ } & \sqrt{ } & \sqrt{ } \\ \sqrt{ } & & & \sqrt{ } \\ \sqrt{ } & & & \sqrt{ } \\ \sqrt{ } & \sqrt{ } & \sqrt{ } & \sqrt{ } \\ \sqrt{ } & \sqrt{ } & \sqrt{ } & \sqrt{ } \\ \sqrt{ } & \sqrt{ } & \sqrt{ } & \sqrt{ } \\ \sqrt{ } & \sqrt{ } & \sqrt{ } & \sqrt{ } \\ & & \sqrt{ } & \sqrt{ } \\ & & & \sqrt{ }\end{array}$

Note: Registrar General Social Class (RGSC) 
Table 2: Distribution of births by maternal age categories and child characteristics, by birth cohort

All births

\begin{tabular}{lllll}
\hline & 1958 & 1970 & 1992 & 2001 \\
Maternal age & & & & \\
$20-24$ & 5.8 & 9.8 & 4.3 & 7.6 \\
$25-29$ & 29.0 & 35.6 & 18.3 & 16.5 \\
$30-34$ & 32.3 & 30.9 & 39.0 & 27.7 \\
$35-39$ & 20.1 & 15.2 & 28.2 & 31.1 \\
40 and over & 10.3 & 6.5 & 9.0 & 15.0 \\
\hline LBW & 2.5 & 2.0 & 1.2 & 2.1 \\
Girl & 6.1 & 7.1 & 5.7 & 6.6 \\
Multiple birth & 48.4 & 48.2 & 48.3 & 48.8 \\
\hline Number of observations & 2.4 & 2.1 & 2.6 & 1.4 \\
\hline
\end{tabular}

First-order births

\begin{tabular}{lllll}
\hline Distribution of births & 1958 & 1970 & 1992 & 2001 \\
under 20 & 13.1 & 21.5 & 8.3 & 15.5 \\
$20-24$ & 44.0 & 47.5 & 23.6 & 20.3 \\
$25-29$ & 29.0 & 22.7 & 41.0 & 29.0 \\
$30-34$ & 10.0 & 5.8 & 21.2 & 25.1 \\
$35-39$ & 3.3 & 2.0 & 5.4 & 9.1 \\
40 and over & 0.6 & 0.6 & 0.5 & 1.0 \\
\hline LBW & 7.1 & 9.0 & 7.3 & 7.8 \\
Girl & 48.7 & 49.2 & 48.9 & 48.4 \\
Multiple birth & 1.7 & 1.6 & 2.0 & 1.6 \\
\hline Number of observations & 6407 & 6370 & 5739 & 7551
\end{tabular}

Note: Sample sizes for the 20 filled-in datasets. Survey weights have been used for the 2001 cohort study. 
Table 3: Odds ratios of LBW for mothers aged 40+ for all births and first-order births, by birth cohort (Models 1 - 4)

\begin{tabular}{|c|c|c|c|}
\hline $\begin{array}{l}\text { Model 1: } \\
\text { Baseline }\end{array}$ & $\begin{array}{l}\text { Model 2: } \\
\text { Baseline + } \\
\text { socio- } \\
\text { demographic } \\
\text { characteristics }\end{array}$ & $\begin{array}{l}\text { Model 3: } \\
\text { Baseline + } \\
\text { health } \\
\text { indicators }\end{array}$ & $\begin{array}{l}\text { Model 4: } \\
\text { Baseline + socio- } \\
\text { demographic } \\
\text { characteristics + } \\
\text { health indicators }\end{array}$ \\
\hline
\end{tabular}

\begin{tabular}{lllcl} 
& \multicolumn{3}{c}{ All births } \\
NCDS 1958 & $1.77^{* * *}$ & $1.67^{* *}$ & $1.59^{* *}$ & $1.53^{* *}$ \\
BCS 1970 & $1.75^{* * *}$ & 1.41 & $1.46^{*}$ & 1.23 \\
ALSPAC 1992 & $1.95^{* *}$ & $2.09^{* *}$ & 1.59 & 1.73 \\
MCS 2001 & 1.39 & $1.66^{* *}$ & 1.18 & 1.44 \\
\hline \multicolumn{5}{c}{ First-order births } \\
NCDS 1958 & $2.57^{* *}$ & $2.63^{* *}$ & $2.17^{*}$ & $2.35^{*}$ \\
BCS 1970 & 2.15 & 1.55 & 1.82 & 1.4 \\
ALSPAC 1992 & 1.3 & 1.37 & 0.99 & 1.02 \\
MCS 2001 & 1.15 & 1.27 & 0.82 & 0.92 \\
\hline
\end{tabular}

Note: Sample sizes for the 20 filled-in datasets. Survey weights have been used for the 2001 cohort study. 


\section{Appendix}

\section{Appendix Figures}

Figure A1: \% LBW by maternal age categories and birth cohort, first-order births

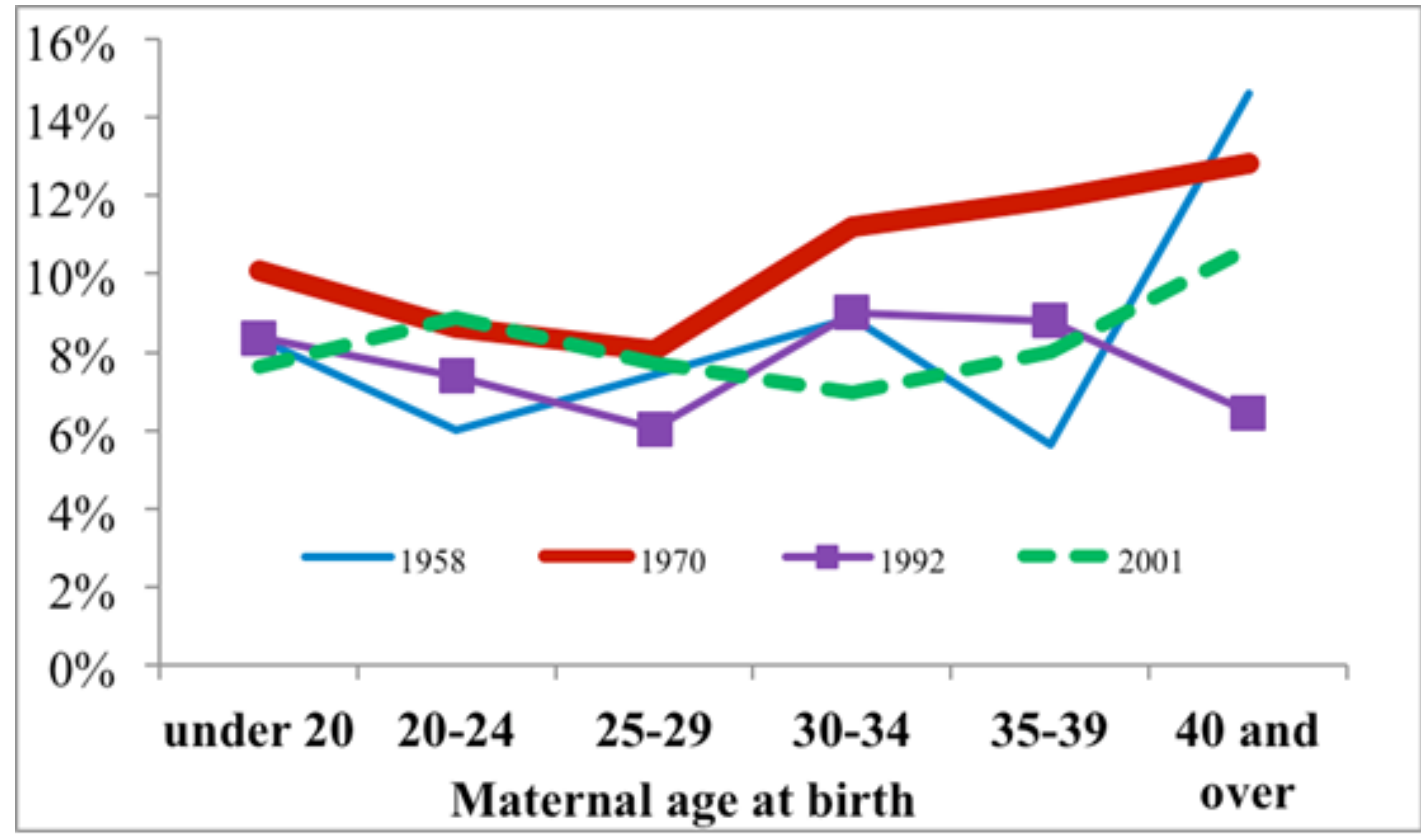

Figure A2: Odds ratios of $\mathrm{LBW}$ for mothers $40+$ for all and first-order births (reference category 20-24), by birth cohort (Model 1)

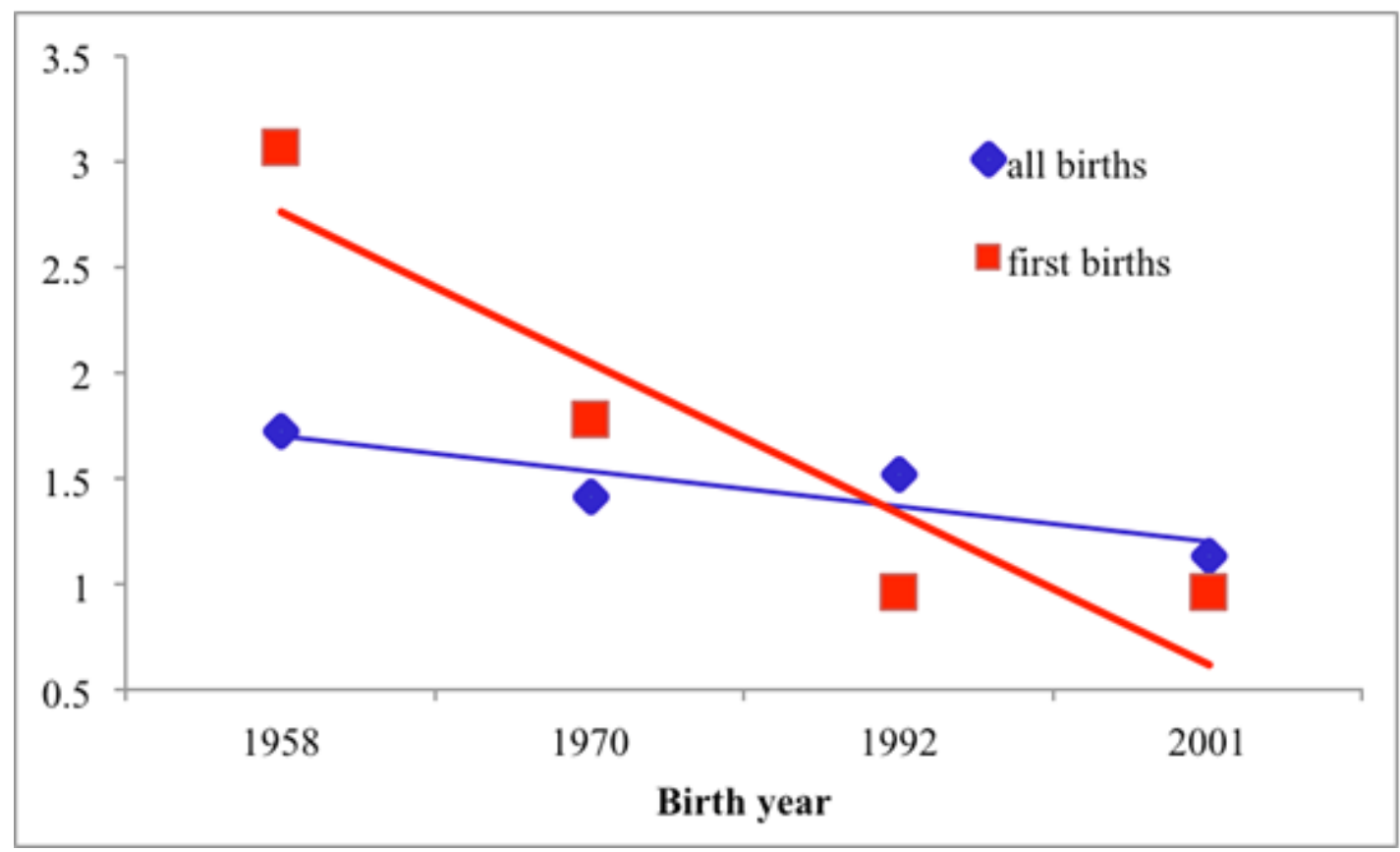




\section{Appendix Tables}

Table A1: Effects of imputations on sample size

\begin{tabular}{lcccc} 
& $\mathbf{1 9 5 8}$ & $\mathbf{1 9 7 0}$ & $\mathbf{1 9 9 2}$ & $\mathbf{2 0 0 1}$ \\
\cline { 2 - 5 } $\begin{array}{l}\text { All order births } \\
\text { Non-imputed }\end{array}$ & 15159 & 14841 & 9091 & 16830 \\
$\begin{array}{l}\text { Imputed } \\
\text { First-order births }\end{array}$ & 16946 & 16811 & 12753 & 17935 \\
$\begin{array}{l}\text { Non-imputed } \\
\text { Imputed }\end{array}$ & 5732 & 5749 & 4030 & 7176 \\
& 6407 & 6370 & 5739 & 7551
\end{tabular}


Table A2: Socio-demographic characteristics for all and first-order births, by maternal age

Mother's partnership status: married at birth $(1958,2001)$ or at conception (1970, 1991)

\begin{tabular}{cccccccc} 
All births & under 20 & $20-24$ & $25-29$ & $30-34$ & $35-39$ & 40 and over & Total \\
\hline 1958 & 83.3 & 95.1 & 97.6 & 97.4 & 97.2 & 96.5 & 96.0 \\
1970 & 59.2 & 90.3 & 98.4 & 98.7 & 99.1 & 99.4 & 91.8 \\
1992 & 20.2 & 56.3 & 82.3 & 86.4 & 82.2 & 77.2 & 76.0 \\
2001 & 7.6 & 31.4 & 62.3 & 75.0 & 74.5 & 71.3 & 59.0 \\
First births & & & & & & & \\
1958 & 81.0 & 94.4 & 96.6 & 95.8 & 95.3 & 95.1 & 93.5 \\
1970 & 52.4 & 82.9 & 96.0 & 96.2 & 97.6 & 97.4 & 80.5 \\
1992 & 19.5 & 54.0 & 81.0 & 82.5 & 73.5 & 71.0 & 69.4 \\
2001 & 6.5 & 29.0 & 63.3 & 74.8 & 69.0 & 71.9 & 51.0 \\
\hline
\end{tabular}

Father or household social class (RGSC): \% High

\begin{tabular}{|c|c|c|c|c|c|c|c|}
\hline All births & under 20 & $20-24$ & $25-29$ & $30-34$ & $35-39$ & 40 and over & Total \\
\hline 1958 & 0.7 & 2.5 & 5.6 & 6.1 & 4.2 & 3.5 & 4.3 \\
\hline 1970 & 1.3 & 3.3 & 7.4 & 6.9 & 5.1 & 4.8 & 5.1 \\
\hline 1992 & 1.0 & 2.2 & 6.7 & 14.7 & 16.7 & 14.2 & 9.0 \\
\hline 2001 & 0.2 & 1.4 & 5.3 & 12.2 & 13.4 & 11.4 & 7.8 \\
\hline \multicolumn{8}{|l|}{ First births } \\
\hline 1958 & 0.7 & 3.1 & 7.3 & 8.4 & 8.5 & 9.8 & 4.7 \\
\hline 1970 & 1.2 & 4.2 & 10.7 & 9.0 & 10.3 & 10.3 & 5.4 \\
\hline 1992 & 1.1 & 2.8 & 8.4 & 18.4 & 19.0 & 27.6 & 9.4 \\
\hline \multirow[t]{2}{*}{2001} & 0.2 & 1.9 & 8.6 & 18.1 & 15.1 & 21.1 & 9.0 \\
\hline & \multicolumn{7}{|c|}{ Father or household social class (RGSC): \% Low } \\
\hline All births & under 20 & $20-24$ & $25-29$ & $30-34$ & $35-39$ & 40 and over & Total \\
\hline 1958 & 11.7 & 10.5 & 8.3 & 8.3 & 8.7 & 10.8 & 9.2 \\
\hline 1970 & 11.4 & 6.7 & 4.4 & 6.5 & 7.9 & 8.4 & 6.5 \\
\hline 1992 & 6.0 & 2.7 & 1.6 & 0.6 & 0.9 & 2.0 & 1.6 \\
\hline 2001 & 5.0 & 3.2 & 1.8 & 1.2 & 1.5 & 1.0 & 2.0 \\
\hline \multicolumn{8}{|l|}{ First births } \\
\hline 1958 & 11.1 & 7.9 & 4.5 & 5.1 & 6.6 & 4.9 & 7.0 \\
\hline 1970 & 9.9 & 4.8 & 1.6 & 4.9 & 5.5 & 0.0 & 5.2 \\
\hline 1992 & 5.4 & 1.4 & 0.7 & 0.4 & 0.3 & 0.0 & 1.1 \\
\hline 2001 & 4.0 & 2.1 & 1.1 & 0.6 & 0.5 & 0.0 & 1.6 \\
\hline
\end{tabular}

Mother's education: \% over the minimum age (1958/1970), degree level (1991/2001)

\begin{tabular}{cccccccc} 
All births & under 20 & $20-24$ & $25-29$ & $30-34$ & $35-39$ & 40 and over & Total \\
\hline 1958 & 14.4 & 22.7 & 28.5 & 27.0 & 23.8 & 24.2 & 25.1 \\
1970 & 26.3 & 31.5 & 41.1 & 34.6 & 36.7 & 35.0 & 34.9 \\
1992 & 0.8 & 1.7 & 9.5 & 21.1 & 26.5 & 14.0 & 12.6 \\
2001 & 2.2 & 11.8 & 32.6 & 43.4 & 48.8 & 47.8 & 33.0 \\
First births & & & & & & & \\
1958 & 14.9 & 24.9 & 34.4 & 35.9 & 37.3 & 36.6 & 27.9 \\
1970 & 28.4 & 38.2 & 53.2 & 44.4 & 54.8 & 51.3 & 40.3 \\
1992 & 0.9 & 2.4 & 14.2 & 28.6 & 31.5 & 16.8 & 14.3 \\
2001 & 2.3 & 16.3 & 46.3 & 55.6 & 58.8 & 64.9 & 37.1 \\
\hline
\end{tabular}




\section{(Table continued)}

Mother's height (mean)

\begin{tabular}{|c|c|c|c|c|c|c|c|}
\hline All births & under 20 & $20-24$ & $25-29$ & $30-34$ & $35-39$ & 40 and over & Total \\
\hline 1958 & 160.0 & 160.7 & 161.3 & 161.2 & 161.0 & 159.9 & 161.0 \\
\hline 1970 & 159.8 & 160.6 & 161.4 & 161.3 & 160.6 & 160.5 & 160.9 \\
\hline 1992 & 163.4 & 163.6 & 164.1 & 164.0 & 164.3 & 163.5 & 164.0 \\
\hline 2001 & 158.8 & 161.3 & 163.2 & 163.6 & 163.5 & 162.0 & 162.7 \\
\hline \multicolumn{8}{|l|}{ First births } \\
\hline 1958 & 160.1 & 160.9 & 161.4 & 161.2 & 161.0 & 160.7 & 161.0 \\
\hline 1970 & 159.9 & 160.9 & 162.0 & 161.6 & 161.6 & 160.9 & 161.0 \\
\hline 1992 & 163.4 & 163.9 & 164.5 & 164.2 & 164.9 & 165.0 & 164.2 \\
\hline \multirow[t]{2}{*}{2001} & 158.2 & 162.5 & 164.4 & 164.8 & 164.7 & 164.3 & 163.2 \\
\hline & \multicolumn{7}{|c|}{ \% Overcrowding } \\
\hline All births & under 20 & $20-24$ & $25-29$ & $30-34$ & $35-39$ & 40 and over & Total \\
\hline 1958 & 25.1 & 15.0 & 11.4 & 12.8 & 18.0 & 20.3 & 14.4 \\
\hline 1970 & N/A & & & & & & \\
\hline 1992 & N/A & & & & & & \\
\hline 2001 & 2.6 & 2.3 & 1.6 & 1.4 & 1.7 & 3.5 & 1.8 \\
\hline \multicolumn{8}{|l|}{ First births } \\
\hline 1958 & 24.3 & 12.4 & 6.3 & 4.0 & 3.6 & 2.6 & 11.0 \\
\hline 1970 & N/A & & & & & & \\
\hline 1992 & N/A & & & & & & \\
\hline 2001 & 2.7 & 1.9 & 0.9 & 0.4 & 0.1 & 0.0 & 1.1 \\
\hline
\end{tabular}

\begin{tabular}{llllllll} 
& \multicolumn{7}{c}{ \% Mother smoked during pregnancy } \\
All births & under 20 & $20-24$ & $25-29$ & $30-34$ & $35-39$ & 40 and over & Total \\
\hline 1958 & 31.9 & 32.7 & 32.1 & 35.5 & 35.1 & 27.8 & 33.1 \\
1970 & 48.0 & 45.2 & 38.1 & 36.2 & 35.9 & 43.7 & 41.3 \\
1992 & 52.6 & 40.6 & 22.9 & 16.6 & 17.1 & 16.3 & 25.0 \\
2001 & 50.5 & 36.7 & 23.0 & 16.4 & 13.6 & 12.7 & 23.7 \\
First births & & & & & & & 29.7 \\
1958 & 32.2 & 29.8 & 26.9 & 33.3 & 33.8 & 24.4 & 39.5 \\
1970 & 46.1 & 41.0 & 33.2 & 29.9 & 33.5 & 36.9 & 25.1 \\
1992 & 51.6 & 37.0 & 19.3 & 15.5 & 15.6 & 12.9 & 21.8 \\
2001 & 48.6 & 30.6 & 15.0 & 10.9 & 10.8 & 4.6 & \\
\hline
\end{tabular}

$\%$ Antenatal visit past 12 weeks of pregnancy

\begin{tabular}{llllllll} 
All births & under 20 & $20-24$ & $25-29$ & $30-34$ & $35-39$ & 40 and over & Total \\
\hline 1958 & 83.7 & 79.5 & 76.6 & 79.6 & 81.4 & 87.6 & 79.2 \\
1970 & 67.3 & 50.5 & 44.3 & 47.4 & 50.5 & 62.8 & 50.0 \\
1992 & 32.6 & 21.5 & 15.4 & 17.4 & 19.0 & 18.7 & 18.2 \\
2001 & 39.7 & 28.5 & 22.1 & 21.5 & 23.0 & 24.5 & 24.5 \\
First births & & & & & & & 74.5 \\
1958 & 82.7 & 75.4 & 69.9 & 71.8 & 77.0 & 84.4 & 48.0 \\
1970 & 66.8 & 45.8 & 36.6 & 42.2 & 39.1 & 69.2 & 16.5 \\
1992 & 30.9 & 19.2 & 12.9 & 14.4 & 18.5 & 10.0 & 23.9 \\
2001 & 40.0 & 26.5 & 18.5 & 19.1 & 21.3 & 22.3 & \\
\hline
\end{tabular}


(Table continued)

\begin{tabular}{llllllll}
\multicolumn{7}{c}{ \% Heavy drinking during pregnancy (1991 during first three months) } \\
\cline { 5 - 6 } & under 20 & $20-24$ & $25-29$ & $30-34$ & $35-39$ & 40 and over & Total \\
\hline 1958 & N/A & & & & & & \\
1970 & N/A & & & & & & \\
1992 & 15.3 & 12.9 & 13.3 & 18.2 & 23.5 & 16.8 & 15.7 \\
2001 & 9.3 & 7.3 & 6.0 & 7.3 & 9.0 & 12.7 & 7.5
\end{tabular}

First births

\begin{tabular}{|c|c|c|c|c|c|c|c|}
\hline 1958 & N/A & & & & & & \\
\hline 1970 & N/A & & & & & & \\
\hline 1992 & 15.5 & 12.8 & 14.3 & 18.5 & 24.5 & 16.1 & 15.5 \\
\hline 2001 & 9.5 & 7.0 & 5.8 & 6.3 & 7.7 & 6.5 & 6.9 \\
\hline
\end{tabular}

Household income: \% high

\begin{tabular}{llllllll} 
All births & under 20 & $20-24$ & $25-29$ & $30-34$ & $35-39$ & 40 and over & Total \\
\hline 1958 & N/A & & & & & & \\
1970 & N/A & & & & & \\
1992 & N/A & & & & & \\
2001 & 1.1 & 3.7 & 16.3 & 29.4 & 35.3 & 28.9
\end{tabular}

\section{First births}

\begin{tabular}{|c|c|c|c|c|c|c|c|}
\hline 1958 & N/A & & & & & & \\
\hline 1970 & N/A & & & & & & \\
\hline 1992 & N/A & & & & & & \\
\hline 2001 & 1.3 & 5.6 & 28.2 & 48.6 & 53.6 & 56.9 & 27.2 \\
\hline & \multicolumn{7}{|c|}{ \% Planned pregnancy } \\
\hline All births & under 20 & $20-24$ & $25-29$ & $30-34$ & $35-39$ & 40 and over & Total \\
\hline 1958 & N/A & & & & & & \\
\hline 1970 & N/A & & & & & & \\
\hline 1992 & N/A & & & & & & \\
\hline 2001 & 15.6 & 38.9 & 62.8 & 69.0 & 66.3 & 50.8 & 57.5 \\
\hline \multicolumn{8}{|c|}{ First births } \\
\hline 1958 & N/A & & & & & & \\
\hline 1970 & N/A & & & & & & \\
\hline 1992 & N/A & & & & & & \\
\hline 2001 & 14.7 & 37.4 & 68.6 & 77.2 & 77.1 & 67.7 & 56.8 \\
\hline
\end{tabular}

Note: sample sizes for the 20 filled-in datasets. Survey weights have been used for the 2001 cohort study. 
Table A3: Mother and child health during pregnancy/labour for all and first births, by maternal age

\section{Previous stillbirths}

\begin{tabular}{cccccccc} 
All births & under 20 & $20-24$ & $25-29$ & $30-34$ & $35-39$ & 40 and over & Total \\
\hline 1958 & 0.2 & 2.7 & 5.4 & 7.5 & 10.9 & 11.7 & 5.5 \\
1970 & 0.2 & 1.3 & 2.7 & 3.3 & 5.4 & 5.7 & 2.3 \\
1992 & 0.4 & 0.3 & 0.6 & 1.0 & 1.4 & 2.5 & 0.8 \\
2001 & 0.3 & 0.6 & 0.5 & 0.7 & 0.8 & 0.8 & 0.6
\end{tabular}

\section{First births}

\begin{tabular}{llllllll}
1958 & 0.2 & 2.3 & 4.1 & 5.8 & 4.7 & 4.9 & 3.0 \\
1970 & 0.3 & 1.1 & 2.0 & 2.2 & 2.4 & 0.0 & 1.2 \\
1992 & 0.4 & 0.2 & 0.5 & 0.5 & 0.6 & 0.0 & 0.4 \\
2001 & & \multicolumn{7}{c}{ too few cases } \\
\hline
\end{tabular}

\begin{tabular}{|c|c|c|c|c|c|c|c|}
\hline \multirow[b]{2}{*}{ All births } & \multicolumn{7}{|c|}{ C-section delivery } \\
\hline & under 20 & $20-24$ & $25-29$ & $30-34$ & $35-39$ & 40 and over & Total \\
\hline 1958 & 0.7 & 1.5 & 2.4 & 3.8 & 4.9 & 8.7 & 2.7 \\
\hline 1970 & 2.4 & 3.0 & 4.1 & 6.8 & 9.9 & 14.8 & 4.5 \\
\hline 1992 & 7.5 & 8.9 & 10.3 & 12.0 & 14.1 & 19.6 & 10.9 \\
\hline 2001 & 11.2 & 15.5 & 19.3 & 24.3 & 27.9 & 35.8 & 21.3 \\
\hline \multicolumn{8}{|l|}{ First births } \\
\hline 1958 & 0.7 & 1.8 & 3.9 & 9.4 & 15.6 & 34.1 & 3.7 \\
\hline 1970 & 2.4 & 3.7 & 6.3 & 13.2 & 23.0 & 43.6 & 5.1 \\
\hline 1992 & 7.5 & 10.8 & 11.7 & 16.6 & 21.3 & 23.5 & 12.7 \\
\hline \multirow[t]{2}{*}{2001} & 11.7 & 18.4 & 23.5 & 29.7 & 37.0 & 66.2 & 23.9 \\
\hline & \multicolumn{7}{|c|}{ Previous miscarriages } \\
\hline All births & under 20 & $20-24$ & $25-29$ & $30-34$ & $35-39$ & 40 and over & Total \\
\hline 1958 & 2.8 & 6.6 & 12.2 & 15.8 & 21.5 & 22.3 & 12.0 \\
\hline 1970 & 4.4 & 9.5 & 16.0 & 22.5 & 25.9 & 29.3 & 14.4 \\
\hline 1992 & 9.5 & 17.3 & 18.3 & 24.3 & 32.1 & 47.2 & 21.0 \\
\hline 2001 & & & & $\mathrm{~N} / \mathrm{A}$ & & & \\
\hline \multicolumn{8}{|l|}{ First births } \\
\hline 1958 & 2.6 & 6.1 & 10.5 & 13.1 & 19.4 & 17.1 & 8.1 \\
\hline 1970 & 4.0 & 7.7 & 13.2 & 15.9 & 19.8 & 17.9 & 8.9 \\
\hline 1992 & 8.9 & 12.9 & 12.4 & 18.2 & 23.0 & 29.4 & 14.1 \\
\hline 2001 & & & & N/A & & & \\
\hline
\end{tabular}

\begin{tabular}{|c|c|c|c|c|c|c|c|}
\hline \multirow[b]{2}{*}{ All births } & \multicolumn{7}{|c|}{ Foetal distress during labour } \\
\hline & under 20 & $20-24$ & $25-29$ & $30-34$ & 35-39 & 40 and over & Total \\
\hline 1958 & 8.9 & 8.0 & 8.3 & 9.6 & 10.7 & 15.7 & 8.9 \\
\hline 1970 & & & & N/A & & & \\
\hline 1992 & & & & N/A & & & \\
\hline 2001 & & & & N/A & & & \\
\hline \multicolumn{8}{|l|}{ First births } \\
\hline 1958 & 9.8 & 12.1 & 17.2 & 29.2 & 43.9 & 68.3 & 16.4 \\
\hline 1970 & & & & N/A & & & \\
\hline 1992 & & & & N/A & & & \\
\hline 2001 & & & & N/A & & & \\
\hline
\end{tabular}


(Table continued)

\begin{tabular}{|c|c|c|c|c|c|c|c|}
\hline \multirow[b]{2}{*}{ All births } & \multicolumn{7}{|c|}{ \% Abnormality during pregnancy (1958: any; 1970: heart rate during delivery) } \\
\hline & under 20 & $20-24$ & $25-29$ & $30-34$ & $35-39$ & 40 and over & Total \\
\hline 1958 & 27.6 & 26.1 & 26.5 & 27.0 & 29.6 & 29.1 & 27.0 \\
\hline 1970 & 11.5 & 12.2 & 14.1 & 16.8 & 21.1 & 26.4 & 13.0 \\
\hline 1992 & \multicolumn{7}{|c|}{ N/A } \\
\hline 2001 & \multicolumn{7}{|c|}{ N/A } \\
\hline \multicolumn{8}{|l|}{ First births } \\
\hline 1958 & 28.4 & 26.7 & 27.4 & 25.6 & 32.5 & 31.7 & 27.2 \\
\hline 1970 & 11.0 & 8.6 & 8.0 & 7.3 & 8.2 & 10.8 & 8.5 \\
\hline 1992 & \multicolumn{7}{|c|}{ N/A } \\
\hline 2001 & \multicolumn{7}{|c|}{ N/A } \\
\hline
\end{tabular}

\% Labour longer than 24 hrs

\begin{tabular}{cccccccc} 
All births & under 20 & $20-24$ & $25-29$ & $30-34$ & $35-39$ & 40 and over & Total \\
\hline 1958 & & \multicolumn{5}{c}{ N/A } \\
1970 & 13.0 & 10.6 & 8.2 & 7.6 & 8.4 & 9.4 & 9.1 \\
1992 & & & \multicolumn{5}{c}{ N/A } \\
2001 & & & N/A
\end{tabular}

\section{First births}

1958

1970

14.5

15.8

17.4

N/A

1992

19.3

23.3

22.0

16.7

2001

N/A

Number of hospital discharges during pregnancy

\begin{tabular}{cccccccc} 
All births & under 20 & $20-24$ & $25-29$ & $30-34$ & $35-39$ & 40 and over & Total \\
\hline 1958 & & \multicolumn{5}{c}{ N/A } \\
1970 & 15.9 & 11.6 & 11.0 & 12.7 & 16.1 & 11.4 & 12.3 \\
1992 & & & \multicolumn{5}{c}{ N/A } \\
2001 & & & N/A
\end{tabular}

\section{First births}

1958

1970

17.2

13.2

12.7

N/A

1992

2001

$\begin{array}{cc}15.9 & 30.9 \\ \text { N/A } & \\ \text { N/A } & \end{array}$

15.4

14.5

\begin{tabular}{|c|c|c|c|c|c|c|c|}
\hline \multirow[b]{2}{*}{ All births } & \multicolumn{7}{|c|}{ \% Mother in good health up to pregnancy } \\
\hline & under 20 & $20-24$ & $25-29$ & $30-34$ & 35-39 & 40 and over & Total \\
\hline 1958 & \multicolumn{7}{|c|}{$\mathrm{N} / \mathrm{A}$} \\
\hline 1970 & \multicolumn{7}{|c|}{ N/A } \\
\hline 1992 & 82.2 & 89.0 & 93.1 & 93.5 & 94.0 & 92.6 & 92.1 \\
\hline 2001 & \multicolumn{7}{|c|}{ N/A } \\
\hline \multicolumn{8}{|l|}{ First births } \\
\hline 1958 & \multicolumn{7}{|c|}{ N/A } \\
\hline 1970 & \multicolumn{7}{|c|}{ N/A } \\
\hline 1992 & 82.2 & 89.1 & 94.0 & 93.7 & 95.0 & 89.8 & 91.9 \\
\hline 2001 & \multicolumn{7}{|c|}{ N/A } \\
\hline
\end{tabular}


(Table continued)

\% Gestational hypertension

\begin{tabular}{|c|c|c|c|c|c|c|c|}
\hline All births & under 20 & $20-24$ & $25-29$ & $30-34$ & $35-39$ & 40 and over & Total \\
\hline 1958 & \multicolumn{7}{|c|}{$\mathrm{N} / \mathrm{A}$} \\
\hline 1970 & \multicolumn{7}{|c|}{ N/A } \\
\hline 1992 & 11.2 & 16.9 & 14.9 & 13.0 & 15.3 & 18.9 & 14.7 \\
\hline 2001 & & & & N/ & & & \\
\hline \multicolumn{8}{|l|}{ First births } \\
\hline 1958 & \multicolumn{7}{|c|}{ N/A } \\
\hline 1970 & \multicolumn{7}{|c|}{ N/A } \\
\hline 1992 & 12.5 & 20.6 & 18.5 & 17.5 & 22.9 & 34.8 & 18.6 \\
\hline 2001 & \multicolumn{7}{|c|}{ N/A } \\
\hline & \multicolumn{7}{|c|}{ \% Any complication during pregnancy } \\
\hline All births & under 20 & $20-24$ & $25-29$ & $30-34$ & $35-39$ & 40 and over & Total \\
\hline 1958 & \multicolumn{7}{|c|}{$\mathrm{N} / \mathrm{A}$} \\
\hline 1970 & \multicolumn{7}{|c|}{ N/A } \\
\hline 1992 & \multicolumn{7}{|c|}{ N/A } \\
\hline 2001 & 40.2 & 41.3 & 39.3 & 39.1 & 39.2 & 34.3 & 39.5 \\
\hline \multicolumn{8}{|l|}{ First births } \\
\hline 1958 & \multicolumn{7}{|c|}{$\mathrm{N} / \mathrm{A}$} \\
\hline 1970 & \multicolumn{7}{|c|}{ N/A } \\
\hline 1992 & \multicolumn{7}{|c|}{ N/A } \\
\hline 2001 & 40.3 & 42.0 & 39.9 & 37.5 & 39.1 & 42.6 & 39.8 \\
\hline
\end{tabular}

Note: Sample sizes for the 20 filled-in datasets. Survey weights have been used for the 2001 cohort study. 
Table A4: Logistic models results regressing LBW on maternal age categories and socio-demographic and health characteristics, for all order births and by birth cohort

\begin{tabular}{|c|c|c|c|c|c|c|c|c|c|}
\hline \multicolumn{5}{|c|}{ NCDS 1958} & \multicolumn{5}{|c|}{ BCS 1970} \\
\hline & (1) & (2) & (3) & (4) & & (1) & (2) & (3) & (4) \\
\hline $\begin{array}{l}\text { Maternal Age <20 } \\
\text { (reference 25-29) }\end{array}$ & $1.33 * *$ & 1.03 & $1.41^{* *}$ & 1.09 & $\begin{array}{l}\text { Maternal Age }<20 \\
\text { (reference 25-29) }\end{array}$ & $1.53^{* * *}$ & 0.96 & $1.67 * * *$ & 1.04 \\
\hline Maternal Age 20-24 & 1.02 & 0.94 & 1.06 & 0.97 & Maternal Age 20-24 & $1.23 * * *$ & 1.02 & $1.31 * * *$ & 1.08 \\
\hline Maternal Age 30-34 & 1.09 & 1.07 & 1.06 & 1.04 & Maternal Age 30-34 & 1.11 & 1.14 & 1.05 & 1.08 \\
\hline Maternal Age 35-39 & 1.19 & 1.14 & 1.1 & 1.07 & Maternal Age 35-39 & 1.25 & 1.16 & 1.09 & 1.04 \\
\hline $\begin{array}{l}\text { Maternal Age } 40 \text { and } \\
\text { over }\end{array}$ & $1.77^{* * *}$ & $1.67 * *$ & $1.59 * *$ & $1.53^{* *}$ & $\begin{array}{l}\text { Maternal Age } 40 \\
\text { and over }\end{array}$ & $1.75^{* * *}$ & 1.41 & $1.46^{*}$ & 1.23 \\
\hline Girl & $1.26^{* * *}$ & $1.26 * * *$ & $1.27^{* * *}$ & $1.27 * * *$ & Girl & $1.18^{* * *}$ & $1.19 * * *$ & $1.20 * * *$ & $1.20^{* * *}$ \\
\hline Multiple birth & $18.8^{* * *}$ & $20.3^{* * *}$ & $20.4^{* * *}$ & $21.9 * * *$ & Multiple birth & $18.1^{* * *}$ & $18.4^{* * *}$ & $18.1^{* * *}$ & $18.3^{* * *}$ \\
\hline $\begin{array}{l}\text { First birth (reference: } \\
\text { higher) }\end{array}$ & $1.49 * * *$ & $1.53^{* * *}$ & $1.50^{* * *}$ & $1.55^{* * *}$ & $\begin{array}{l}\text { First birth } \\
\text { (reference: higher) }\end{array}$ & $1.58^{* * *}$ & $2.04 * * *$ & $1.54^{* * *}$ & $1.96 * * *$ \\
\hline $\begin{array}{l}\text { Social class I } \\
\text { (reference: social class } \\
\text { III) }\end{array}$ & & 0.78 & & 0.76 & $\begin{array}{l}\text { Social class I } \\
\text { (reference: social } \\
\text { class III) }\end{array}$ & & 1.01 & & 1.02 \\
\hline Social class II & & 1.02 & & 1.02 & Social class II & & 0.95 & & 0.98 \\
\hline Social class III & & 0.98 & & 0.98 & Social class III & & 0.92 & & 0.94 \\
\hline Social class VI & & 1.04 & & 1.02 & Social class VI & & $1.28 * * *$ & & $1.28^{* * *}$ \\
\hline Social class V & & 1.13 & & 1.12 & Social class V & & $1.25^{*}$ & & $1.24 *$ \\
\hline $\begin{array}{l}\text { Social class not } \\
\text { available, no man in } \\
\text { hh, unemployed, sick, } \\
\text { dead }\end{array}$ & & 1.06 & & 1.08 & $\begin{array}{l}\text { Social class not } \\
\text { available, no man in } \\
\text { hh, unemployed, } \\
\text { sick, dead }\end{array}$ & & 1.57 & & 1.56 \\
\hline Mother employed & & 1.09 & & 1.09 & $\begin{array}{l}\text { Mother stayed in } \\
\text { school beyond } \\
\text { minimum age }\end{array}$ & & 0.92 & & 0.93 \\
\hline $\begin{array}{l}\text { Overcrowded } \\
\text { household }\end{array}$ & & $1.27 * * *$ & & $1.26 * *$ & $\begin{array}{l}\text { Premarital } \\
\text { conception }\end{array}$ & & 0.85 & & 0.91 \\
\hline Mother married at birth & & $0.63^{* *}$ & & $0.62 * *$ & $\begin{array}{l}\text { Mother smoked } \\
\text { during pregnancy }\end{array}$ & & $1.82^{* * *}$ & & $1.81 * * *$ \\
\hline $\begin{array}{l}\text { Mother stayed in } \\
\text { school beyond } \\
\text { minimum age }\end{array}$ & & $0.81^{* *}$ & & $0.82 * *$ & $\begin{array}{l}\text { Antenatal care after } \\
12 \text { weeks of } \\
\text { pregnancy }\end{array}$ & & $2.83^{* * *}$ & & $2.82 * * *$ \\
\hline $\begin{array}{l}\text { Mother smoked during } \\
\text { pregnancy }\end{array}$ & & $1.55^{* * *}$ & & $1.58 * * *$ & Mother's height & & $0.95^{* * *}$ & & $0.95 * * *$ \\
\hline $\begin{array}{l}\text { Antenatal care after } 12 \\
\text { weeks of pregnancy }\end{array}$ & & 0.97 & & 1 & $\begin{array}{l}\text { Mother has had } \\
\text { stillbirths }\end{array}$ & & & $1.77 * * *$ & $1.46 * *$ \\
\hline Mother's height & & $0.90 * * *$ & & $0.91 * * *$ & $\begin{array}{l}\text { Mother has } \\
\text { miscarriages }\end{array}$ & & & $1.52 * * *$ & $1.45^{* * *}$ \\
\hline $\begin{array}{l}\text { Mother has had } \\
\text { stillbirths }\end{array}$ & & & $1.45^{* * *}$ & $1.34 * *$ & C-section delivery & & & $1.95^{* * *}$ & $1.80^{* * *}$ \\
\hline $\begin{array}{l}\text { Mother has had } \\
\text { miscarriages }\end{array}$ & & & $1.20 *$ & 1.16 & $\begin{array}{l}\text { Child has abnormal } \\
\text { heart rate during } \\
\text { delivery }\end{array}$ & & & $1.33 * *$ & $1.27 * *$ \\
\hline C-section delivery & & & $1.72 * * *$ & $1.70^{* * *}$ & $\begin{array}{l}\text { Number of } \\
\text { discharges during } \\
\text { pregnancy }\end{array}$ & & & $1.21^{* * *}$ & $1.15^{* *}$ \\
\hline Foetal distress & & & 1.08 & 1.04 & $\begin{array}{l}\text { Number of } \\
\text { observations }\end{array}$ & & & & \\
\hline Abnormality & & & $1.47 * * *$ & $1.46^{* * *}$ & & & & & \\
\hline $\begin{array}{l}\text { Labour longer than } \\
24 \mathrm{hrs}\end{array}$ & & & $0.80 *$ & $0.80^{*}$ & & & & & \\
\hline $\begin{array}{l}\text { Number of } \\
\text { observations }\end{array}$ & & & & & & & & & \\
\hline
\end{tabular}


(Table continued)

\begin{tabular}{|c|c|c|c|c|c|c|c|c|c|}
\hline \multicolumn{5}{|c|}{ ALSPAC 1992} & \multicolumn{5}{|c|}{ MCS 2001} \\
\hline & (1) & (2) & (3) & (4) & & (1) & (2) & (3) & (4) \\
\hline $\begin{array}{l}\text { Maternal Age <20 } \\
\text { (reference 25-29) }\end{array}$ & $1.51^{* *}$ & 1.05 & $1.58^{* *}$ & 1.11 & $\begin{array}{l}\text { Maternal Age <20 } \\
\text { (reference 25-29) }\end{array}$ & 1.2 & $0.68 * *$ & $1.37 * *$ & $0.76^{*}$ \\
\hline Maternal Age 20-24 & $1.28^{* *}$ & 1.04 & $1.32 * *$ & 1.08 & $\begin{array}{l}\text { Maternal Age 20- } \\
24\end{array}$ & $1.22 *$ & 0.92 & $1.27 *$ & 0.95 \\
\hline Maternal Age 30-34 & 0.99 & 1.07 & 0.94 & 1.03 & $\begin{array}{l}\text { Maternal Age 30- } \\
34\end{array}$ & 0.95 & 1.1 & 0.89 & 1.03 \\
\hline Maternal Age 35-39 & $1.39 * *$ & $1.60^{* * *}$ & 1.27 & $1.47 * *$ & $\begin{array}{l}\text { Maternal Age 35- } \\
39\end{array}$ & 1.02 & $1.24 *$ & 0.91 & 1.11 \\
\hline $\begin{array}{l}\text { Maternal Age } 40 \text { and } \\
\text { over }\end{array}$ & $1.95^{* *}$ & $2.09 * *$ & 1.59 & 1.73 & $\begin{array}{l}\text { Maternal Age } 40 \\
\text { and over }\end{array}$ & 1.39 & $1.66 * *$ & 1.18 & 1.44 \\
\hline Girl & 1 & 1 & 1.02 & 1.03 & Girl & $1.15^{* *}$ & $1.17 * *$ & $1.17^{* *}$ & $1.19 * *$ \\
\hline Multiple birth & $21.8^{* * *}$ & $23.1 * * *$ & $19.7^{* * *}$ & $20.5^{* * *}$ & Multiple birth & $19.6^{* * *}$ & $23.5^{* * *}$ & $15.8^{* * *}$ & $18.8^{* * *}$ \\
\hline $\begin{array}{l}\text { First birth (reference: } \\
\text { higher) }\end{array}$ & $2.00 * * *$ & $2.22 * * *$ & $1.86^{* * *}$ & $2.02^{* * *}$ & $\begin{array}{l}\text { First birth } \\
\text { (reference: higher) }\end{array}$ & $1.38^{* * *}$ & $1.75^{* * *}$ & $1.30^{* * *}$ & $1.65^{* * *}$ \\
\hline $\begin{array}{l}\text { Social class I } \\
\text { (reference: social } \\
\text { class III) }\end{array}$ & & 1.03 & & 1.01 & $\begin{array}{l}\text { Social class I } \\
\text { (reference: social } \\
\text { class III) }\end{array}$ & & 0.79 & & 0.84 \\
\hline Social class II & & 1.07 & & 1.07 & Social class II & & 0.86 & & 0.9 \\
\hline Social class III & & 1.07 & & 1.08 & Social class III & & 0.9 & & 0.91 \\
\hline Social class VI & & $1.47 * *$ & & $1.47 * *$ & Social class VI & & 1.07 & & 1.1 \\
\hline Social class V & & 1.22 & & 1.2 & Social class V & & 1.28 & & 1.29 \\
\hline $\begin{array}{l}\text { Mother has degree } \\
\text { level education }\end{array}$ & & $0.74 *$ & & 0.78 & $\begin{array}{l}\text { Social class not } \\
\text { available, no man } \\
\text { in hh, unemployed, } \\
\text { sick, dead }\end{array}$ & & 1.26 & & $1.35 *$ \\
\hline $\begin{array}{l}\text { Mother cohabiting at } \\
\text { conception } \\
\text { (reference: } \text { married) }\end{array}$ & & 1.13 & & 1.15 & $\begin{array}{l}\text { Mother has degree } \\
\text { level education }\end{array}$ & & 0.86 & & $0.83^{*}$ \\
\hline $\begin{array}{l}\text { Mother single at } \\
\text { conception }\end{array}$ & & 0.96 & & 0.92 & $\begin{array}{l}\text { Mother married at } \\
\text { birth }\end{array}$ & & 1.02 & & 0.99 \\
\hline $\begin{array}{l}\text { Mother smoke during } \\
\text { pregnancy }\end{array}$ & & $1.78^{* * *}$ & & $1.80^{* * *}$ & $\begin{array}{l}\text { Mother cohabiting } \\
\text { at birth }\end{array}$ & & 1.12 & & 1.12 \\
\hline Mother's height & & $0.96^{* * *}$ & & $0.97^{* * *}$ & $\begin{array}{l}\text { Household } \\
\text { income: top } \\
\text { quintile }\end{array}$ & & 0.9 & & 0.88 \\
\hline $\begin{array}{l}\text { Light drinkg during } \\
\text { first trimester } \\
\text { (reference: no } \\
\text { drinking) }\end{array}$ & & 0.89 & & 0.91 & $\begin{array}{l}\text { Overcrowded } \\
\text { household }\end{array}$ & & 0.94 & & 1.03 \\
\hline $\begin{array}{l}\text { Heavy drinking } \\
\text { during first trimester }\end{array}$ & & $0.81 *$ & & $0.81^{*}$ & $\begin{array}{l}\text { Mother smoked } \\
\text { during pregnancy }\end{array}$ & & $1.99 * * *$ & & $1.98^{* * *}$ \\
\hline $\begin{array}{l}\text { Antenatal care after } \\
12 \text { weeks of } \\
\text { pregnancy }\end{array}$ & & 1.09 & & 1.13 & $\begin{array}{l}\text { Light drinkg } \\
\text { during pregnancy } \\
\text { (reference: no } \\
\text { drinking) }\end{array}$ & & $0.83^{*}$ & & 0.87 \\
\hline $\begin{array}{l}\text { Mother has had } \\
\text { miscarriages }\end{array}$ & & & 1.04 & 0.98 & $\begin{array}{l}\text { Heavy drinking } \\
\text { during pregnancy }\end{array}$ & & 0.98 & & 1.03 \\
\hline C-section delivery & & & $3.57^{* * *}$ & $3.33^{* * *}$ & $\begin{array}{l}\text { Pregnancy was } \\
\text { planned }\end{array}$ & & 0.91 & & 0.92 \\
\hline $\begin{array}{l}\text { Mother in good } \\
\text { health up to } \\
\text { pregnancy }\end{array}$ & & & $0.68^{* * *}$ & $0.71 * *$ & Mother's height & & $0.023 * * *$ & & $0.036^{* * *}$ \\
\hline Gestational hyper & & & 1.05 & 1.14 & $\begin{array}{l}\text { Antenatal care } \\
\text { after } 12 \text { weeks of } \\
\text { pregnancy }\end{array}$ & & 1.1 & & $1.17^{*}$ \\
\hline $\begin{array}{l}\text { Mother has had } \\
\text { stillbirths }\end{array}$ & & & $1.96 *$ & 1.73 & $\begin{array}{l}\text { Mother has had } \\
\text { stillbirths }\end{array}$ & & & $3.77 * * *$ & $3.23 * * *$ \\
\hline $\begin{array}{l}\text { Number of } \\
\text { observations }\end{array}$ & & & & & C-section delivery & & & $2.59^{* * *}$ & $2.51^{* * *}$ \\
\hline & & & & & $\begin{array}{l}\text { Complications } \\
\text { during pregnancy }\end{array}$ & & & $1.83^{* * *}$ & $1.91^{* * *}$ \\
\hline & & & & & $\begin{array}{l}\text { Number of } \\
\text { observations }\end{array}$ & & & & \\
\hline
\end{tabular}

Notes: All models shown (1)-(4) include covariates groups MAB + CHILDEM. Model (2) additionally includes MATSOCIODEM, model (3) HEALTH, and model (4) both MATSOCIODEM and HEALTH. See the discussion of equations (1)-(4) in section Statistical analyses. Numbers shown are odds ratios, and stars mark significance at the $10 \%, 5 \%$, and $1 \%$ levels. 
Table A5: Logistic models results regressing LBW on maternal age categories and socio-demographic and health characteristics, for first-order births and by birth cohort

\begin{tabular}{|c|c|c|c|c|c|c|c|c|c|}
\hline \multicolumn{5}{|c|}{ NCDS 1958} & \multicolumn{5}{|c|}{ BCS 1970} \\
\hline & (1) & (2) & (3) & (4) & & (1) & (2) & (3) & (4) \\
\hline $\begin{array}{l}\text { Maternal Age <20 } \\
\text { (reference 25-29) }\end{array}$ & 1.25 & 0.94 & 1.29 & 0.98 & $\begin{array}{l}\text { Maternal Age }<20 \\
\text { (reference 25-29) }\end{array}$ & $1.52 * * *$ & 0.96 & $1.59 * * *$ & 0.99 \\
\hline Maternal Age 20-24 & 0.84 & $0.76^{* *}$ & 0.85 & $0.78 * *$ & Maternal Age 20-24 & 1.21 & 1.01 & $1.25 *$ & 1.04 \\
\hline Maternal Age 30-34 & 1.21 & 1.2 & 1.19 & 1.19 & Maternal Age 30-34 & $1.60^{* *}$ & $1.52 * *$ & $1.54 * *$ & $1.47^{*}$ \\
\hline Maternal Age 35-39 & 0.71 & 0.69 & 0.65 & 0.65 & Maternal Age 35-39 & 1.57 & 1.53 & 1.37 & 1.37 \\
\hline $\begin{array}{l}\text { Maternal Age } 40 \text { and } \\
\text { over }\end{array}$ & $2.57 * *$ & $2.63^{* *}$ & $2.17 *$ & $2.35^{*}$ & $\begin{array}{l}\text { Maternal Age } 40 \\
\text { and over }\end{array}$ & 2.15 & 1.55 & 1.82 & 1.4 \\
\hline Girl & $1.23^{* *}$ & $1.22 *$ & $1.23 * *$ & $1.22 *$ & Girl & 1.09 & 1.08 & 1.1 & 1.08 \\
\hline Multiple birth & $29.9^{* * *}$ & $32.4 * * *$ & $31.4^{* * *}$ & $33.5^{* * *}$ & Multiple birth & $29.1^{* * *}$ & $29.9 * * *$ & $28.9 * * *$ & $29.6^{* * *}$ \\
\hline $\begin{array}{l}\text { Social class I } \\
\text { (reference: social } \\
\text { class III) }\end{array}$ & & 1.1 & & 1.07 & $\begin{array}{l}\text { Social class I } \\
\text { (reference: social } \\
\text { class III) }\end{array}$ & & 1.02 & & 1.03 \\
\hline Social class II & & 1.18 & & 1.2 & Social class II & & 1.14 & & 1.17 \\
\hline Social class III & & 1.11 & & 1.12 & Social class III & & 1.14 & & 1.17 \\
\hline Social class VI & & 1.28 & & 1.27 & Social class VI & & $1.40^{* * *}$ & & $1.40^{* * *}$ \\
\hline Social class V & & 1.22 & & 1.19 & Social class V & & $1.57 * *$ & & $1.57 * *$ \\
\hline $\begin{array}{l}\text { Social class not } \\
\text { available, no man in } \\
\text { hh, unemployed, sick, } \\
\text { dead }\end{array}$ & & 1.22 & & 1.23 & $\begin{array}{l}\text { Social class not } \\
\text { available, no man in } \\
\text { hh, unemployed, } \\
\text { sick, dead }\end{array}$ & & 0.55 & & 0.56 \\
\hline Mother employed & & 1.12 & & 1.13 & $\begin{array}{l}\text { Mother stayed in } \\
\text { school beyond } \\
\text { minimum age }\end{array}$ & & 0.94 & & 0.94 \\
\hline $\begin{array}{l}\text { Overcrowded } \\
\text { household }\end{array}$ & & $1.56^{* * *}$ & & $1.55^{* * *}$ & $\begin{array}{l}\text { Premarital } \\
\text { conception }\end{array}$ & & 0.95 & & 0.99 \\
\hline $\begin{array}{l}\text { Mother married at } \\
\text { birth }\end{array}$ & & 0.7 & & 0.7 & $\begin{array}{l}\text { Mother smoked } \\
\text { during pregnancy }\end{array}$ & & $1.53^{* * *}$ & & $1.52 * * *$ \\
\hline $\begin{array}{l}\text { Mother stayed in } \\
\text { school beyond } \\
\text { minimum age }\end{array}$ & & 0.92 & & 0.92 & $\begin{array}{l}\text { Antenatal care after } \\
12 \text { weeks of } \\
\text { pregnancy }\end{array}$ & & $2.51 * * *$ & & $2.50 * * *$ \\
\hline $\begin{array}{l}\text { Mother smoked } \\
\text { during pregnancy }\end{array}$ & & $1.46^{* * *}$ & & $1.46^{* * *}$ & Mother's height & & $0.95^{* * *}$ & & $0.95^{* * *}$ \\
\hline $\begin{array}{l}\text { Antenatal care after } \\
12 \text { weeks of } \\
\text { pregnancy }\end{array}$ & & 0.96 & & 0.96 & $\begin{array}{l}\text { Mother has had } \\
\text { stillbirths }\end{array}$ & & & 1.72 & 1.35 \\
\hline Mother's height & & $0.88^{* * *}$ & & $0.89^{* * *}$ & $\begin{array}{l}\text { Mother has } \\
\text { miscarriages }\end{array}$ & & & 1.24 & 1.25 \\
\hline $\begin{array}{l}\text { Mother has had } \\
\text { stillbirths }\end{array}$ & & & 0.84 & 0.81 & C-section delivery & & & $1.41^{*}$ & 1.3 \\
\hline $\begin{array}{l}\text { Mother has had } \\
\text { miscarriages }\end{array}$ & & & $1.39 *$ & $1.40 *$ & $\begin{array}{l}\text { Child has abnormal } \\
\text { heart rate during } \\
\text { delivery }\end{array}$ & & & 1.24 & 1.17 \\
\hline C-section delivery & & & $1.71^{* *}$ & $1.70^{*}$ & $\begin{array}{l}\text { Number of } \\
\text { discharges during } \\
\text { pregnancy }\end{array}$ & & & $1.25^{* *}$ & $1.20^{*}$ \\
\hline Foetal distress & & & 0.98 & 0.91 & $\begin{array}{l}\text { Number of } \\
\text { observations }\end{array}$ & & 6,3 & & \\
\hline Abnormality & & & $1.30^{* *}$ & $1.25 *$ & & & & & \\
\hline $\begin{array}{l}\text { Labour longer than } \\
24 \mathrm{hrs}\end{array}$ & & & $0.62 * * *$ & $0.62^{* * *}$ & & & & & \\
\hline $\begin{array}{l}\text { Number of } \\
\text { observations }\end{array}$ & & & & & & & & & \\
\hline
\end{tabular}


(Table continued)

\begin{tabular}{|c|c|c|c|c|c|c|c|c|c|}
\hline \multicolumn{5}{|c|}{ ALSPAC 1992} & \multicolumn{5}{|c|}{ MCS 2001} \\
\hline & (1) & (2) & (3) & (4) & & (1) & (2) & (3) & (4) \\
\hline $\begin{array}{l}\text { Maternal Age }<20 \\
\text { (reference 25-29) }\end{array}$ & $1.65^{* * *}$ & 1.25 & $1.75^{* * *}$ & 1.32 & $\begin{array}{l}\text { Maternal Age } \\
<20 \text { (reference } \\
25-29 \text { ) }\end{array}$ & 1.09 & 0.76 & 1.23 & 0.84 \\
\hline Maternal Age 20-24 & $1.36^{* *}$ & 1.15 & $1.36 * *$ & 1.16 & $\begin{array}{l}\text { Maternal Age } \\
20-24\end{array}$ & 1.2 & 0.98 & 1.25 & 1.02 \\
\hline Maternal Age 30-34 & $1.28 *$ & $1.34^{*}$ & 1.19 & 1.26 & $\begin{array}{l}\text { Maternal Age } \\
30-34\end{array}$ & 0.86 & 0.93 & 0.83 & 0.9 \\
\hline Maternal Age 35-39 & $1.54 *$ & $1.68^{* *}$ & 1.32 & 1.47 & $\begin{array}{l}\text { Maternal Age } \\
35-39\end{array}$ & 0.96 & 1.03 & 0.85 & 0.91 \\
\hline $\begin{array}{l}\text { Maternal Age } 40 \text { and } \\
\text { over }\end{array}$ & 1.3 & 1.37 & 0.99 & 1.02 & $\begin{array}{l}\text { Maternal Age } \\
40 \text { and over }\end{array}$ & 1.15 & 1.27 & 0.82 & 0.92 \\
\hline Girl & 1.06 & 1.06 & 1.08 & 1.09 & Girl & $1.24 * *$ & $1.29 * *$ & $1.27^{* *}$ & $1.32 * *$ \\
\hline Multiple birth & $28.2 * * *$ & $31.5^{* * *}$ & $25.8^{* * *}$ & $27.9 * * *$ & Multiple birth & $32.2^{* * *}$ & $37.3^{* * *}$ & $27.7 * * *$ & $32.5 * * *$ \\
\hline $\begin{array}{l}\text { Social class I } \\
\text { (reference: social class } \\
\text { III) }\end{array}$ & & 1.33 & & 1.35 & $\begin{array}{l}\text { Social class I } \\
\text { (reference: } \\
\text { social class } \\
\text { III) }\end{array}$ & & $0.58 * *$ & & $0.62 *$ \\
\hline Social class II & & 1.2 & & 1.19 & Social class II & & $0.69 *$ & & $0.71 *$ \\
\hline Social class III & & 1.15 & & 1.17 & Social class III & & 0.77 & & 0.78 \\
\hline Social class VI & & 1.31 & & 1.24 & Social class VI & & 0.72 & & 0.75 \\
\hline Social class V & & $2.28 *$ & & $2.20 *$ & Social class V & & 0.77 & & 0.82 \\
\hline $\begin{array}{l}\text { Mother has degree level } \\
\text { education }\end{array}$ & & 0.72 & & 0.76 & $\begin{array}{l}\text { Social class } \\
\text { not available, } \\
\text { no man in hh, } \\
\text { unemployed, } \\
\text { sick, dead }\end{array}$ & & 0.75 & & 0.8 \\
\hline $\begin{array}{l}\text { Mother cohabiting at } \\
\text { conception (reference: } \\
\text { married) }\end{array}$ & & 1.16 & & 1.2 & $\begin{array}{l}\text { Mother has } \\
\text { degree level } \\
\text { education }\end{array}$ & & 0.95 & & 0.91 \\
\hline $\begin{array}{l}\text { Mother single at } \\
\text { conception }\end{array}$ & & 0.85 & & 0.85 & $\begin{array}{l}\text { Mother } \\
\text { married at } \\
\text { birth }\end{array}$ & & 0.75 & & $0.73^{*}$ \\
\hline $\begin{array}{l}\text { Mother smoke during } \\
\text { pregnancy }\end{array}$ & & $1.64^{* * *}$ & & $1.68^{* * *}$ & $\begin{array}{l}\text { Mother } \\
\text { cohabiting at } \\
\text { birth }\end{array}$ & & 0.88 & & 0.89 \\
\hline Mother's height & & $0.95 * * *$ & & $0.96 * * *$ & $\begin{array}{l}\text { Household } \\
\text { income: top } \\
\text { quintile }\end{array}$ & & 0.95 & & 0.99 \\
\hline $\begin{array}{l}\text { Light drinkg during } \\
\text { first trimester } \\
\text { (reference: no drinking) }\end{array}$ & & 0.9 & & 0.92 & $\begin{array}{l}\text { Overcrowded } \\
\text { household }\end{array}$ & & 0.61 & & 0.63 \\
\hline $\begin{array}{l}\text { Heavy drinking during } \\
\text { first trimester }\end{array}$ & & 0.76 & & 0.76 & $\begin{array}{l}\text { Mother } \\
\text { smoked during } \\
\text { pregnancy }\end{array}$ & & $1.45^{* * *}$ & & $1.44^{* * *}$ \\
\hline $\begin{array}{l}\text { Antenatal care after } 12 \\
\text { weeks of pregnancy }\end{array}$ & & 1.08 & & 1.12 & $\begin{array}{l}\text { Light drinkg } \\
\text { during } \\
\text { pregnancy } \\
\text { (reference: no } \\
\text { drinking) } \\
\text { heavy }\end{array}$ & & 0.99 & & 1.04 \\
\hline $\begin{array}{l}\text { Mother has had } \\
\text { miscarriages }\end{array}$ & & & 1.02 & 0.95 & $\begin{array}{l}\text { drinking } \\
\text { during } \\
\text { pregnancy }\end{array}$ & & 0.85 & & 0.87 \\
\hline C-section delivery & & & $3.67 * * *$ & $3.33^{* * *}$ & $\begin{array}{l}\text { Pregnancy } \\
\text { was planned }\end{array}$ & & 1.17 & & 1.21 \\
\hline $\begin{array}{l}\text { Mother in good health } \\
\text { up to pregnancy }\end{array}$ & & & 0.73 & $0.72 *$ & $\begin{array}{l}\text { Mother's } \\
\text { height }\end{array}$ & & $0.010^{* * *}$ & & $0.015^{* * *}$ \\
\hline Gestational hyper & & & 1.15 & 1.26 & $\begin{array}{l}\text { Antenatal care } \\
\text { after } 12 \text { weeks } \\
\text { of pregnancy }\end{array}$ & & 1.19 & & $1.27 * *$ \\
\hline $\begin{array}{l}\text { Mother has had } \\
\text { stillbirths }\end{array}$ & & & 1.12 & 1.12 & $\begin{array}{l}\text { Mother has } \\
\text { had stillbirths }\end{array}$ & & & - & - \\
\hline Number of observations & & & & & $\begin{array}{l}\text { C-section } \\
\text { delivery }\end{array}$ & & & $2.22 * * *$ & $2.09^{* * *}$ \\
\hline & & & & & $\begin{array}{l}\text { Complications } \\
\text { during } \\
\text { pregnancy } \\
\text { Number of } \\
\text { observations }\end{array}$ & & & $2.01^{* * *}$ & $2.08 * * *$ \\
\hline
\end{tabular}

Notes: All models shown (1)-(4) include covariates groups MAB + CHILDEM. Model (2) additionally includes MATSOCIODEM, model (3) HEALTH, and model (4) both MATSOCIODEM and HEALTH. See the discussion of equations (1)-(4) in section Statistical analyses. Numbers shown are odds ratios, and stars mark significance at the $10 \%, 5 \%$, and $1 \%$ levels. 
Table A6: Results from pooled model for the 1958 and 2001 cohort studies

Reference category 25-29

\begin{tabular}{ccc} 
& \multicolumn{3}{c}{ All births } \\
OR & P-value & $95 \%$ CI \\
1.61 & 0.042 & $1.02-2.33$ \\
0.8 & 0.457 & $0.42-1.47$ \\
\multicolumn{3}{c}{ First births } \\
2.58 & 0.103 & $0.81-5.68$ \\
0.45 & 0.224 & $0.10-1.95$
\end{tabular}

Reference category 20-24

All births

1958 NCDS*40+

$2001 \mathrm{MCS}^{*} 40+$

1958 NCDS*40+

2001 MCS*40+

OR P-value 95\% CI

1958 NCDS*40+

$1.43 \quad 0.1 \quad 0.90-2.10$

2001 MCS*40+

$0.72 \quad 0.262 \quad 0.36-1.31$

First births

1958 NCDS*40+

$0.069 \quad 0.90-6.63$

2001 MCS*40+

$\begin{array}{lll}3.08 & 0.069 & 0.90-6.63 \\ 0.31 & 0.087 & 0.07-1.32\end{array}$


Table A7: Logistic models results regressing LBW on maternal age categories and socio-demographic and health characteristics setting as reference category mothers aged $\mathbf{2 0 - 2 4}$, for all/first-order births and by birth cohort

\begin{tabular}{|c|c|c|c|c|c|c|c|c|c|c|c|c|c|c|c|c|c|c|c|}
\hline \multicolumn{5}{|c|}{ NCDS 1958} & \multicolumn{5}{|c|}{ BCS 1970} & \multicolumn{5}{|c|}{ ALSPAC 1992} & \multicolumn{5}{|c|}{ MCS 2001} \\
\hline & (1) & (2) & (3) & (4) & & (1) & (2) & (3) & (4) & & (1) & (2) & (3) & (4) & & (1) & (2) & (3) & (4) \\
\hline \multicolumn{5}{|c|}{ All order births } & \multicolumn{5}{|c|}{ All order births } & \multicolumn{6}{|c|}{ All order births } & \multicolumn{4}{|c|}{ All order births } \\
\hline $\begin{array}{l}\text { Maternal Age } \\
<20 \text { (reference } \\
20-24)\end{array}$ & $1.30^{*}$ & 1.09 & $1.33^{* *}$ & 1.12 & $\begin{array}{l}\text { Maternal Age } \\
<20 \text { (reference } \\
20-24)\end{array}$ & $1.24 * *$ & 0.94 & $1.28^{* *}$ & 0.96 & $\begin{array}{l}\text { Maternal Age } \\
<20 \text { (reference } \\
20-24)\end{array}$ & 1.18 & 1.01 & 1.2 & 1.03 & $\begin{array}{l}\text { Maternal Age } \\
<20 \text { (reference } \\
20-24)\end{array}$ & 0.98 & $0.74^{* *}$ & 1.07 & 0.8 \\
\hline $\begin{array}{l}\text { Maternal Age } \\
25-29\end{array}$ & 0.98 & 1.07 & 0.94 & 1.03 & $\begin{array}{l}\text { Maternal Age } \\
25-29\end{array}$ & $0.81^{* * *}$ & 0.98 & $0.76 * * *$ & 0.92 & $\begin{array}{l}\text { Maternal Age } \\
25-29\end{array}$ & $0.78^{* *}$ & 0.96 & $0.76^{* *}$ & 0.93 & $\begin{array}{l}\text { Maternal Age } \\
25-29\end{array}$ & $0.82^{*}$ & 1.09 & $0.79^{*}$ & 1.06 \\
\hline $\begin{array}{l}\text { Maternal Age } \\
\text { 30-34 }\end{array}$ & 1.06 & 1.14 & 0.99 & 1.07 & $\begin{array}{l}\text { Maternal Age } \\
30-34\end{array}$ & 0.9 & 1.11 & $0.80^{* *}$ & 1 & $\begin{array}{l}\text { Maternal Age } \\
30-34\end{array}$ & $0.77 * *$ & 1.04 & $0.71^{* * *}$ & 0.96 & $\begin{array}{l}\text { Maternal Age } \\
30-34\end{array}$ & $0.78^{* *}$ & 1.2 & $0.70^{* * * *}$ & 1.09 \\
\hline $\begin{array}{l}\text { Maternal Age } \\
\text { 35-39 }\end{array}$ & 1.17 & 1.22 & 1.04 & 1.1 & $\begin{array}{l}\text { Maternal Age } \\
\text { 35-39 }\end{array}$ & 1.01 & 1.14 & 0.84 & 0.96 & $\begin{array}{l}\text { Maternal Age } \\
\text { 35-39 }\end{array}$ & 1.08 & $1.54^{* *}$ & 0.96 & $1.36^{*}$ & $\begin{array}{l}\text { Maternal Age } \\
\text { 35-39 }\end{array}$ & 0.84 & $1.36^{* *}$ & $0.71^{* *}$ & 1.17 \\
\hline $\begin{array}{l}\text { Maternal Age } \\
40 \text { and over }\end{array}$ & $1.73^{* * *}$ & $1.78^{* * *}$ & $1.50^{* *}$ & $1.58^{* *}$ & $\begin{array}{l}\text { Maternal Age } \\
40 \text { and over }\end{array}$ & $1.42^{*}$ & 1.37 & 1.12 & 1.14 & $\begin{array}{l}\text { Maternal Age } \\
40 \text { and over }\end{array}$ & 1.52 & $2.02 * *$ & 1.21 & 1.6 & $\begin{array}{l}\text { Maternal Age } \\
40 \text { and over }\end{array}$ & 1.14 & $1.81^{* *}$ & 0.92 & 1.53 \\
\hline \multicolumn{6}{|c|}{ First-order births } & \multicolumn{4}{|c|}{ First-order births } & \multicolumn{6}{|c|}{ First-order births } & \multicolumn{4}{|c|}{ First-order births } \\
\hline $\begin{array}{l}\text { Maternal Age } \\
<20 \text { (reference } \\
20-24)\end{array}$ & $1.50 * * *$ & 1.24 & $1.52 * * *$ & 1.26 & $\begin{array}{l}\text { Maternal Age } \\
<20 \text { (reference } \\
20-24)\end{array}$ & $1.25^{* *}$ & 0.95 & $1.27^{* *}$ & 0.95 & $\begin{array}{l}\text { Maternal Age } \\
<20 \text { (reference } \\
20-24)\end{array}$ & 1.22 & 1.09 & 1.28 & 1.13 & $\begin{array}{l}\text { Maternal Age } \\
<20 \text { (reference } \\
20-24)\end{array}$ & 0.91 & 0.78 & 0.98 & 0.82 \\
\hline $\begin{array}{l}\text { Maternal Age } \\
25-29\end{array}$ & 1.19 & $1.31^{* *}$ & 1.17 & $1.29 * *$ & $\begin{array}{l}\text { Maternal Age } \\
25-29\end{array}$ & 0.83 & 0.99 & $0.80^{*}$ & 0.96 & $\begin{array}{l}\text { Maternal Age } \\
25-29\end{array}$ & $0.74^{* *}$ & 0.87 & $0.73^{* *}$ & 0.86 & $\begin{array}{l}\text { Maternal Age } \\
25-29\end{array}$ & 0.83 & 1.02 & 0.8 & 0.98 \\
\hline $\begin{array}{l}\text { Maternal Age } \\
30-34\end{array}$ & $1.45^{* *}$ & $1.57^{* *}$ & $1.40^{*}$ & $1.53^{* *}$ & $\begin{array}{l}\text { Maternal Age } \\
\text { 30-34 }\end{array}$ & 1.32 & $1.51^{* *}$ & 1.23 & $1.41^{*}$ & $\begin{array}{l}\text { Maternal Age } \\
\text { 30-34 }\end{array}$ & 0.94 & 1.17 & 0.87 & 1.09 & $\begin{array}{l}\text { Maternal Age } \\
30-34\end{array}$ & $0.71^{* *}$ & 0.95 & $0.66^{* *}$ & 0.88 \\
\hline $\begin{array}{l}\text { Maternal Age } \\
\text { 35-39 }\end{array}$ & 0.84 & 0.9 & 0.76 & 0.83 & $\begin{array}{l}\text { Maternal Age } \\
\text { 35-39 }\end{array}$ & 1.29 & 1.51 & 1.09 & 1.31 & $\begin{array}{l}\text { Maternal Age } \\
\text { 35-39 }\end{array}$ & 1.14 & 1.47 & 0.97 & 1.26 & $\begin{array}{l}\text { Maternal Age } \\
\text { 35-39 }\end{array}$ & 0.8 & 1.05 & $0.68^{*}$ & 0.89 \\
\hline $\begin{array}{l}\text { Maternal Age } \\
40 \text { and over }\end{array}$ & $3.07^{* *}$ & $3.45^{* * *}$ & $2.55^{* *}$ & $3.04^{* *}$ & $\begin{array}{l}\text { Maternal Age } \\
40 \text { and over }\end{array}$ & 1.78 & 1.53 & 1.45 & 1.35 & $\begin{array}{l}\text { Maternal Age } \\
40 \text { and over }\end{array}$ & 0.96 & 1.19 & 0.73 & 0.88 & $\begin{array}{l}\text { Maternal Age } \\
40 \text { and over }\end{array}$ & 0.96 & 1.3 & 0.66 & 0.9 \\
\hline
\end{tabular}

Notes: All models shown (1)-(4) include covariates groups MAB + CHILDEM. Model (2) additionally includes MATSOCIODEM, model (3) HEALTH, and model (4) both MATSOCIODEM and HEALTH. See the discussion of equations (1)-(4) in section Statistical analyses. Numbers shown are odds ratios, and stars mark significance at the $10 \%, 5 \%$, and $1 \%$ levels. 
${ }^{\mathrm{i}}$ The 1946 National Survey of Health and Development was not included in this study because of the selected characteristics of its sample (which excluded stillbirths, twins, and children born to unmarried mothers); the reduced level of covariates available for this cohort compared to the levels for the other cohorts; and the smaller sample size, which would have raised power issues in some of the analyses.

ii Ethical approval for the study was obtained from the ALSPAC Ethics and Law Committee and the Local Research Ethics Committees.

iii Please note that the study website contains details of all the data that are available through a fully searchable data dictionary which can be accessed on the following webpage: http://www.bris.ac.uk/alspac/researchers/data-access/data-dictionary/

${ }^{i v}$ In the ALSPAC, stillbirths were included in the original sample, but birth weight was not recorded for them. In the MCS, stillbirths were not part of the sample.

${ }^{\mathrm{v}}$ We could not impute birth order since some of the regression models were run on first-order births only.

${ }^{\text {vi }}$ We controlled for whether the cohort member was a first- or a higher-order birth. Studies have shown that first-born children tend to be lighter than later-born children (Seidman et al., 1988). In the baseline model, we did not include adjustment for whether the child was a second-, a third-, or a higher-order birth, since large family size could be a marker of low socio-economic status in the family. In Model 2 or 4, adjustment for whether the cohort member was a second-/third-/higher-order birth did not change the results.

vii The primary task when pooling survey data is to find a way of accounting for the differences in survey design. The NCDS and the MCS studies are substantially different with respect to their sampling schemes. As was outlined in the text, the NCDS surveyed its entire population, which consisted of all of the babies born in a particular week of March 1958. By contrast, the population of the MCS consisted of all of the babies born in the UK during roughly one year within the 2000-2001 period. In addition, the MCS features a complex survey design, including the multi-stage sampling and oversampling of certain groups. In order to pool the data we made the following adjustments and assumptions: We first adopted the view that the NCDS sampled from a larger population; namely, all of the babies born during the whole of March 1958. This rests on the assumption that the births during the actual NCDS week of 1958 did not differ systematically from the other births during March 1958. The effect of viewing the NCDS as sampling from a larger population necessitates the usage of (grossing up) weights with a value of four. All of the NCDS births were assigned to a common stratum, but each one received its own primary sampling unit. For the MCS, we applied the unaltered settings of its complex survey design, with the exception of grossing up the weights in order to make the survey population size equal to the number of babies born in the UK in the year 2000. The values for the finite population correction for the MCS were not changed, and the corresponding values for the NCDS observations were set to $1 / 4$. Based on these settings, the standard errors were calculated using a nonparametric bootstrap with 1000 replications. In order to generate replicate weights for the pooled data, we made use of the Stata module bs weights (Kolenikov, 2010). We reported confidence intervals and p-values based on percentile calculations of the distribution of the bootstrap parameter estimates. We also repeated the same estimation by grossing up NCDS observations to the entire year of 1958 . The results remained unchanged. 